\title{
Spatial heterogeneity of methane concentration, diffusion and production potential, and methanogen community abundance and diversity in sediments from Lake Remoray (France)
}

\author{
Vincent Tardy ( $\sim$ vpm.tardy@gmail.com ) \\ Universite Savoie Mont-Blanc https://orcid.org/0000-0001-9592-8343 \\ David Etienne \\ Universite Savoie Mont-Blanc \\ Laurent Millet \\ Université de Franche-Comté / CNRS \\ Emilie Lyautey \\ Universite Savoie Mont-Blanc
}

\section{Research Article}

Keywords: Hypoxia, lake sediments, co-occurrence network, methanogen communities, methanogenesis

Posted Date: October 27th, 2021

DOI: https://doi.org/10.21203/rs.3.rs-1004466/v1

License: (c) (1) This work is licensed under a Creative Commons Attribution 4.0 International License.

Read Full License 


\section{Abstract}

Lake ecosystems contribute significantly to atmospheric methane and are likely to become even bigger methane emitters with the global spread of hypoxia/anoxia in freshwater ecosystems. Here we characterized the spatial heterogeneity of methane production potential, methane concentration, archaeal and bacterial and methanogen communities across Lake Remoray sediment during the summer period, when hypoxic conditions settle in the deepest part of the water column. It was hypothesized that methane concentration and production would be higher in the deeper part of lake, our results showed that some littoral areas exhibited similar or higher values than the deepest area. The full 16S rRNA gene sequencing dataset counted 41 methanogen OTUs in abundances that depended more on sampling-site location than on the water depth gradient. The methanogen co-occurrence network revealed the existence of 5 distinct sub communities, suggesting the presence of different methanogen niches across Lake Remoray. The variation in abundance of the two larger methanogen sub communities was significantly related to methanogenesis potential and sediment methane concentration across-lake. Taken together, our results highlight the need to consider the ecosystem at whole-lake scale when calculating methane budgets, and the need to couple spatial and temporal approaches in order to better estimate lake ecosystems contribution to atmospheric methane.

\section{Introduction}

Methane ranks just behind carbon dioxide as a major greenhouse gas, with an 12-year lifetime in the atmosphere, a global warming potential 72 times higher than $\mathrm{CO}_{2}$ over a 20-year timescale (25 times higher over 100 years), and a radiative forcing of $+0.48 \mathrm{~W} \mathrm{~m}^{-2}$ [1]. Methane concentration in the atmosphere is currently about $1850 \mathrm{ppb}$ [2], which is an increase of more than $150 \%$ since the preindustrial era and rising fast at the unprecedented rate of $>5 \mathrm{ppb} \mathrm{yr}^{-1}$ in the 2004-2017 period [2].

Atmospheric methane is mostly anthropogenic: fossil fuel extraction and agricultural practices account for about $73 \%$ of methane emissions. Other sources are natural: wetlands ecosystems are the biggest natural source of atmospheric methane, followed by lake ecosystems which account for $6-16 \%$ of nonanthropogenic emissions [3], i.e. up to $76 \mathrm{Tg} \mathrm{C}^{-} \mathrm{CH}_{4}$ emitted to the atmosphere per year [4]. Recent models project that lake emissions will increase under the combined effects of rising temperature $[5,6]$ and global-scale eutrophication of water bodies [7]. The isotopic signature of atmospheric methane is also changing, as $\delta^{13} \mathrm{C}^{-} \mathrm{CH}_{4}$ has fallen from $-47.06 \%$ o to $-47.36 \%$ in less than 10 years, likely reflecting changes in both sources and sinks of atmospheric methane [2].

Microbial actors of the methane cycle are the methanogenic archaea, which are involved under anoxic conditions in the final stage of reducing organic matter (OM) into methane [8], and methanotrophic organisms (archaea and bacteria) that oxidize, with efficiencies ranging from $30 \%$ to $99 \%$ in lake ecosystems [9],) methane under both anaerobic and aerobic conditions into carbon dioxide [10, 11]. In lakes, methanogenesis mainly takes place in the sediment compartment and in the deeper water column layers under temporary or permanent anoxic conditions [12]. Methane oxidation occurs aerobically when 
carried out by methanotrophic bacteria or anaerobically in the presence of sulfates or nitrates as terminal electron acceptors when carried out by methanotrophic Archaea [13]. If not oxidized, methane can be emitted to the atmosphere through four well-described pathways: bubbling, diffusion, by lake overturn when methane trapped in the hypolimnion is released, and via flows related to aquatic plants and roots that facilitate sediment-water column gas exchanges [3].

Among the abiotic factors likely to affect the methane cycle, those that vary spatially and seasonally and with stratification of the water column will define the location of the oxic/anoxic interface and influence methanogenic and methanotrophic community diversity and activity rates [14-17]. Methane oxidation dynamics are influenced by concentration of methane [18], oxygen [19-21] or nitrogen [21] and by methanotroph grazing by benthic invertebrates [22], whereas methanogenesis depends more on redox potential [23], quality and quantity of available OM [9], and temperature [20]. In particular, it has been shown that methane production in lake sediments is correlated with the $\mathrm{C} / \mathrm{N}$ ratio of $\mathrm{OM}$ : methane production rates are higher at $\mathrm{C} / \mathrm{N}<10$ [20]. This suggests that methanogenic and methanotrophic communities are likely to be sensitive to variations in redox potential but also to qualitative and quantitative variations in OM inputs. At lake scale, seasonally-driven water column stratification maximizes the spatial occurrence of favourable redox methanogenesis conditions in the hypolimnion [24], and thermal stratification is expected to last for longer periods in future global climate change scenarios [25-27].

Here we aimed to assess the spatial heterogeneity of methane concentrations, diffusive fluxes and potential production rates in the sediment compartment of Lake Remoray (France). Lake Remoray is characterized by eutrophication due to $\mathrm{OM}$, nutrient and contaminant inputs from the watershed, and by long periods of hypoxia in the deep water column (Belle et al., 2016). In July 2017, sediment cores were collected from 10 sampling sites across the 95-ha lake. Environmental descriptors were related to physicochemistry of the sediment compartment (OM content). Abundances of archaeal and bacterial communities involved in methane production and oxidation were assessed by targeting mcrA (methyl coenzyme $\mathrm{M}$ reductase) and $p m o \mathrm{~A}$ (particulate methane monooxygenase) as functional markers. Diversity, structure and composition of sediment archaeal and bacterial communities were assessed using an Illumina sequencing approach targeting $16 \mathrm{~S}$ ribosomal RNA (rRNA) genes. The whole sequencing dataset served to characterize the methanogen communities by co-occurrence network analysis.

We expected that (i) methane concentration, production and diffusion would be higher in sediment from the deeper zones due to extensive recent $\mathrm{OM}$ accumulation and to the longer time period of anoxia in overlying water column layers, and that (ii) spatial variations in sediment methane concentration, production and diffusion would be related to the diversity and to their metabolic genetic potentials (i.e. abundance) of the in-sediment methanogenic communities.

\section{Materials And Methods}


Study site and core collection

Lake Remoray (46 $46^{\prime} 12^{\prime \prime} \mathrm{N} ; 6^{\circ} 15^{\prime} 49^{\prime \prime} \mathrm{E}$; Fig. 1) is located in the Jura Mountains (eastern France). The water depth of this moderately-sized lake ( $95 \mathrm{ha}$ ) reaches $27 \mathrm{~m}$. The lake is currently meso-eutrophic, with an accumulation of organic matter in the central and deepest part of the lake [29]. It is fed by two tributaries (the Drésine and the Lhaut), has one outlet (the Taverne) (Fig. 1), and is bordered by a farm and a campsite. The catchment basin of Lake Remoray consists of $46.7 \%$ forest (mainly coniferous forest), $42.5 \%$ agricultural land, $5.5 \%$ peat bog, $2.6 \%$ water area, and $2.7 \%$ urban area [28].

In 2017 (July $4^{\text {th }}$ and $5^{\text {th }}$ ), short 90-mm-diameter sediment cores were collected at 10 sampling sites located all over the lake using a UWITEC gravity corer (Fig. 1). The 10 sites were selected out of the 44 sites analyzed previously (Tardy et al., In press), to include the deepest site [\#1441] along with littoralzone ( $<5 \mathrm{~m}$ ) and profundal-zone (about $20 \mathrm{~m}$ deep) sites representing the 4 characteristic areas of the lake: tributaries [\#1413,\#1414 and \#1434], outlet [\#1398 and \#1427], campsite [\#1409 and \#1439], and farm [\#1419 and \#1440] (Fig. 2). At sampling time, water temperature at the water - sediment interface was of $5^{\circ} \mathrm{C}$ for the deeper sites and $21.7^{\circ} \mathrm{C}$ for the shallower sites. Two littoral sites were included in the tributaries area to include the potential influence of the Drésine and the Lhaut on the lake. Two cores were collected at each site, and the first 10 centimetres of sediment from the sediment water interface in each core was sub-sampled directly in the field. For the first core, sediment samples were collected through a pre-pierced liner using precut autoclaved syringes at determined sampling depths ( $n=10$, every centimetre for the first 10 centimetres), and used for biogeochemical measurements $\left(\mathrm{CH}_{4}\right.$ concentrations and diffusive flux calculations) and microbiological analyses (molecular-based analyses). For the second sediment core, sediment samples were extruded using a core extruder and 2-cm sediment sections were collected using a core cutter ( $n=5$, every two centimetres for the 10 first centimetres) to serve for biogeochemical measurements (potential activity rates) and sedimentological analysis.

Sediment characteristics

Sediment particle size distribution was determined by laser diffraction on dry sediments (Mastersizer S, Malvern, United Kingdom), and particles were grouped by median grain size. Sediment water content was estimated by drying at $60^{\circ} \mathrm{C}$ for $48 \mathrm{~h}$. Organic matter (OM) content was measured by loss-on-ignition [30]. Organic carbon $(\mathrm{OC})$ content and porosity were calculated from water and $\mathrm{OM}$ contents using formulas provided elsewhere [31].

Methane concentrations and fluxes

Sediment samples $(0.5 \mathrm{~mL})$ subsampled from the sediment core every centimetre through pre-pierced holes were placed into glass vials with $\mathrm{NaOH}$ ( $4 \mathrm{~mL}$ of $2.5 \% \mathrm{NaOH}$ in 20 -mL vials), covered with a butyl stopper, and sealed with an aluminium crimp. Dissolved $\mathrm{CH}_{4}$ concentrations were measured in the headspace by gas chromatography using an Agilent 490 MicroGC thermal conductivity detector equipped with a PoraPLOT Q column with helium as vector gas. 
Methane fluxes (Js) were calculated based on Fick's first law using the top $10 \mathrm{~cm}$ of measured $\mathrm{CH}_{4}$ concentrations. The equation from Maerki et al., (2004) was used to correct for porosity and tortuosity. The $\mathrm{CH}_{4}$ diffusion coefficient, $\mathrm{D}$, was interpolated by sampling site water temperature at the watersediment interface according to Lerman (1979). Js was calculated according to Sollberger et al., (2014) as follows:

$$
J s=-\frac{D}{F} \times \frac{\delta C H_{4}}{\delta z}
$$

Methane production potential

$\mathrm{CH}_{4}$ production potentials were measured as described in Fuchs et al. (2016) by incubating lake sediment under controlled conditions. Immediately following field sampling, wet sediment from each targeted 2-cm section of extruded sediment was placed in a flask, filled to the top to exclude air capture, sealed, and stored at $4^{\circ} \mathrm{C}$ until potential activity measurements. For $\mathrm{CH}_{4}$ production potential, $5-10 \mathrm{~g}$ of wet sediment was transferred to $150 \mathrm{~mL}$ flasks added with $10 \mathrm{~mL}$ of demineralized water. The flasks were hermetically sealed with rubber caps, inerted with helium, and incubated at $20^{\circ} \mathrm{C}$ under constant moderate agitation during the course of the experiment. Methane concentrations were then measured by gas chromatography $(\mathrm{n}=1)$ at $\mathrm{t} 0=1 \mathrm{~h}$ (allowing $1 \mathrm{~h}$ of medium equilibration) and at $5 \mathrm{~h}$ using the Agilent 490 MicroGC thermal conductivity detector. For each flask, dry weights of incubated sediments were determined after drying at $105^{\circ} \mathrm{C}$ for $48 \mathrm{~h}$. Methane production was expressed as $\mathrm{ng}$ of $\mathrm{C}-\mathrm{CH}_{4} \mathrm{~g}^{-1}$ sediment dry weight [DW] $\mathrm{h}^{-1}$ based on the increase in $\mathrm{CH}_{4}$ concentrations.

Molecular analyses

Samples for nucleic acid-based analyses were collected using pre-cut autoclaved syringes, transferred to cryovials, immediately stored on liquid nitrogen in the field, taken back to the lab and held at $-20^{\circ} \mathrm{C}$ until nucleic acid extraction was realized. Total DNA was extracted from $0.5 \mathrm{~g}$ of wet sediment using a NucleoSpin Soil Kit following the manufacturer's instructions, and using SL1 lysis buffer and additive Enhancer SX buffer (Macherey-Nagel, Hoerdt, France). The extracted DNA was quantified fluorometrically after staining with QuantiFluor dsDNA Dye (QuantiFluor dsDNA System, Promega, Charbonnières-lesBains, France) using a Plate Chameleon ${ }^{\text {TM }}$ fluorometer (Hidex, Turku, Finland; excitation: 485 nm, emission: $590 \mathrm{~nm}$ ).

The abundances of total and functional organisms were assessed by quantitative PCR targeting the $16 \mathrm{~S}$ rRNA, mcrA and $p m o A$ genes. Real-time PCR was carried out in triplicate on DNA extracts for each sample. For $16 \mathrm{~S}$ rRNA gene analysis, reactions were done in a final volume of $25 \mu \mathrm{L}$ containing $1 \times$ Brilliant II SYBR ${ }^{8}$ Green QPCR Master Mix (Agilent), $0.3 \mathrm{mg} \mathrm{mL}^{-1}$ bovine serum albumin (Sigma-Aldrich), $0.3 \mu \mathrm{M}$ of each primer (EUB-341F: 5'-CCT ACG GGA GGC AGC AG-3' and EUB-515R: 5'-ATT ACC GCG GCT GCT GG-3'; López-Gutiérrez et al., 2004), and $0.5 \mu \mathrm{L}$ DNA extract. Thermal cycling conditions were an 
initial cycle of $95^{\circ} \mathrm{C}$ for $10 \mathrm{~min}, 45 \mathrm{cycles}$ of $95^{\circ} \mathrm{C}$ for $15 \mathrm{sec}, 60^{\circ} \mathrm{C}$ for $30 \mathrm{sec}$ and $72^{\circ} \mathrm{C}$ for $30 \mathrm{sec}$, and then a melt-curve step $\left(55^{\circ} \mathrm{C}\right.$ to $\left.95^{\circ} \mathrm{C}\right)$. A plasmid containing a single copy of $16 \mathrm{~S}$ rRNA genes amplified from Escherichia coli (Bacteria) was diluted from $10^{8}$ to $10^{1}$ copies per assay and used in triplicate to produce the standard curve. Amplification efficiency was 105\%. Methanogen and methanotroph abundance was evaluated by quantitative PCR on mcrA and pmoA genes using the protocol described in Fuchs et al. (2016) but with a final qPCR mix adjusted to $25 \mu \mathrm{L}$. Reactions were performed in a final volume of $25 \mu \mathrm{L}$ containing $1 \times$ Brilliant II SYBR Green QPCR Master Mix (Agilent), $0.3 \mathrm{mg} \mathrm{mL}^{-1}$ bovine serum albumin (Sigma-Aldrich), $0.5 \mu \mathrm{M}$ of primers ME1 and ME2 [36] and A189f and mb661r [37] for $m c r A$ and $p m o A$ assays, respectively, and $2 \mathrm{ng}$ of template DNA. A plasmid containing a single copy of mcrA gene amplified from a Methanosarcina thermophila affiliated clone (KR011363) and pmoA gene amplified from Methylomonas methanica DSMZ 25384 DNA extract was diluted from $10^{7}$ to $10^{1}$ molecules per assay. Samples and standards were used in triplicate. Amplification efficiencies were $93 \%$ for $m c r A$ and $99 \%$ for pmoA. One or two copies of $m c r A$ per genome is reported [38] while two copies of the $p m o A$ gene were assumed to be present per cell [39].

PCR amplification for high-throughput 16S rRNA sequencing was carried out with the universal primer pair 515F (5'-GTGYCAGCMGCCGCGGTA-3') and 909R (5'-CCCCGYCAATTCMTTTRAGT-3') targeting the hypervariable V4-V5 region of the 16S rRNA gene [40]. Indexes were integrated to both primers following the dual-indexing procedure described by Kozich et al. (2013). Triplicate PCR amplifications for each sample were realized with a total amount of $\sim 5 \mathrm{ng}$ of DNA per reaction. Amplicons were quantified using a PicoGreen ${ }^{\text {TM }}$ assay (Life Technologies, Carlsbad, CA) and pooled equimolarly. The final pool was purified using CleanPCR beads (CleanNA). Sequencing was realized by Fasteris (Geneva, Switzerland) on an Illumina HiSeq 2500 system with $2 \times 250 \mathrm{bp}$. Analysis yielded $6.7 \mathrm{~Gb}$ of sequences with average error rate of $0.822 \%$ and an average Q30 of $90.3 \%$.

Bioinformatics analysis

Adapter sequences were removed using Trimmomatic [42] and barcode-sorted using a Fasteris internal script (Perl script). Sequences were then processed using the FROGS (Find Rapidly OTUs with Galaxy Solution) Galaxy-supported pipeline [43]. Paired-end reads were joined using FLASH [44] and qualitychecked using FastQC. Sequences with non-mismatching primers were kept and then filtered by size (between 350 and $500 \mathrm{bp}$ ), and those containing $\mathrm{N}$ bases were discarded. The 16S rRNA gene sequences were then denoised and clustered using the Swarm method [45] with a maximum 3-bases difference. Clusters having less than $0.005 \%$ abundance and with occurrence in less than two samples of the total library were deleted. Chimeras were removed using the vchime tool of the vsearch package [46]. Affiliation was done using the Silva SSU database v.123 [47] via BLAST [48] with multiple affiliation allowed and manual curation. All analyses were done on the Galaxy instance of the INRA MIGALE bioinformatics platform (http://migale.jouy.inra.fr). The raw datasets are available in the European Bioinformatics Institute (EBI) database system (in the European Nucleotide Archive) under project accession number PRJEB 43875. 
Methane production potential, methane concentration, methane diffusion, microbial density, $m c r A / 16 S$ rRNA genes ratio and $p m o A / 16 S$ rRNA genes ratio were compared between the littoral and profundal zones of Lake Remoray using a nonparametric Kruskal-Wallis test for each stratum of sediment core samples.

Based on the taxonomic classification, methanogen sequences were extracted from sequencing dataset. We used all the orders of methanogen known in literature and which represented by Methanobacteriales, Methanomassiliicoccales, Methanomicrobiales, Methanosarcinales, Methanomethyliales and Methanofastidiosales [8]. Spatial variations in archaeal and bacterial, and methanogen community structure across Lake Remoray were characterized using UniFrac distance [49]. Nonmetric multidimensional scaling (NMDS) was used to graphically depict spatial variations between the archaeal and bacterial, and methanogen communities. The significance of the observed clustering of samples on the ordination plot was assessed by analysis of variance using distance matrices (ADONIS test, 999 permutations).

We used the 'DESeq2' R package [50] to calculate the significant changes in methanogen composition (log2 fold change in relative abundance of each OTU) between the littoral and profundal zones of Lake Remoray. Differences in methanogen OTU abundances between in-lake depth zones were considered significant if their adjusted $\mathrm{p}$-values were $<0.01$.

The methanogen community co-occurrence network was built using the 'igraph' R package. Pearson correlations between all pairs of 41 OTUs (OTUs found in at least 15 samples) were calculated, and the pvalues were adjusted using Benjamini-Hochberg $(\mathrm{BH})$ method [51]. Only significant correlations $(p<0.05$, post-BH correction) with $\mathrm{R}>0.5$ were graphed. Network modules (subcommunities in the network) were identified using the 'WGCNA' R package [52] on the adjacency matrix of Pearson correlation values between each pair of OTUs with a thresholding power of 6 . The adjacency matrix was transformed into a topological overlap matrix (TOM) to minimize possible errors, and the OTUs were clustered in modules with a minimum number of three OTUs per module. Modules having $<0.3$ dissimilarity in eigengenes were subsequently merged, and Pearson correlations between merged modules and the methane functional parameter dataset $\left(\mathrm{CH}_{4}\right.$ production, $\mathrm{CH}_{4}$ and $\mathrm{OM}$ concentration, and mcrA/16S rRNA genes ratio) were calculated.

All statistical analyses were performed using with the free R software (version 3.5.3).

\section{Results}

Sediments characteristics

Sediment texture was relatively similar between the different sampling sites of Lake Remoray, with about $73 \%$ silt, $25 \%$ sand and $2 \%$ clay (Fig. 2). Only sampling site \#1413 close to the Lhaut tributary had a 
different sediment texture, with $19 \%$ silt, $81 \%$ sand and less than $1 \%$ clay.

Organic matter (OM) and organic carbon (OC) content in the first 10 centimetres of sediment cores varied from $6.3 \%$ to $38 \%$ and from $3.7 \%$ to $22 \%$, respectively, depending on sampling-site location (Fig. 2). The highest $\mathrm{OM}$ and $\mathrm{OC}$ contents were found at sampling site \#1414 close to lake tributaries, with in average for the first $10 \mathrm{~cm}$ of the sediment core containing an average $24 \% \mathrm{OM}$ and $14 \% \mathrm{OC}$. The deepest sampling site (\#1441) was characterized by $12 \%$ OM content and $7.8 \%$ OC content.

Methane production potential, concentration and diffusion across Lake Remoray

Methane production potential, concentration and diffusion were not related to water depth at the sampling site (littoral vs profundal zone) and were not significantly different between stratum depths along sediment cores (Kruskal-Wallis test in all sediment strata; data not shown) (Fig. 3).

In the profundal zone, methane production potential was maximal in the first $2 \mathrm{~cm}$ of sediment cores (Fig. 3a). The highest methane potential production was recorded at the deepest sampling site, with $6563 \mathrm{ng}$ $\mathrm{C}^{-} \mathrm{CH}_{4} \mathrm{~g} \mathrm{DW}^{-1} \mathrm{~h}^{-1}$. Methane production potential decreased gradually along the strata of sediment cores at all profundal-zone sampling sites. Average methane production potential in the littoral zone varied from

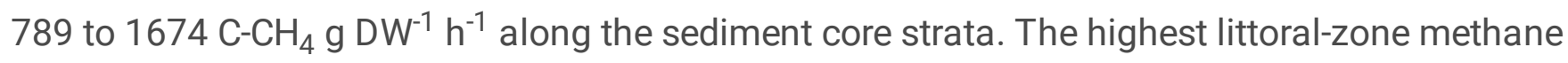

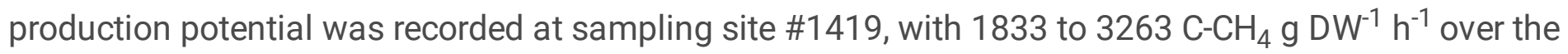
first $10 \mathrm{~cm}$ of the sediment core. The lowest methane production potential was recorded at sampling sites \#1413 and \#1414, with an average of 179 and $705 \mathrm{C}^{-\mathrm{CH}_{4}} \mathrm{~g} \mathrm{DW}^{-1} \mathrm{~h}^{-1}$, respectively, over the first 10 $\mathrm{cm}$ of the sediment core.

Methane concentrations increased with sediment core depth (Fig. 3b), ranging from 2 to $8.2 \mathrm{mg} \mathrm{CH}_{4} \mathrm{~L}^{-1}$ for littoral-zone cores and 2.6 to $11 \mathrm{mg} \mathrm{CH}_{4} \mathrm{~L}^{-1}$ for profundal-zone cores. The deepest sampling site (\#1441) had the highest methane concentrations along the sediment core. Sampling site \#1413, in the tributaries area, had the lowest methane concentrations in the sediment core.

Calculations of methane diffusion along the first $10 \mathrm{~cm}$ of the sediment cores found higher average diffusive $\mathrm{CH}_{4}$ fluxes in the profundal zone (Fig. 3c). The highest $\mathrm{CH}_{4}$ fluxes were recorded at profundalzone sites \#1439 and \#1440 (192 and $200 \mathrm{mg} \mathrm{CH}_{4} \mathrm{~m}^{-2}$ day $^{-1}$, respectively). The lowest fluxes were recorded at littoral-zone sampling sites \#1413 and \#1414 (-4 and -7 $\mathrm{mg} \mathrm{CH}_{4} \mathrm{~m}^{-2}$ day $\left.^{-1}\right)$.

Genetic potential of methane cycle functioning across Lake Remoray

Whatever the sampling-depth zone, bacterial densities assessed as 16S rRNA gene copies g-1 DW (Fig. 4a) decreased from top to bottom of the sediment cores. No significant differences were observed between littoral and profundal zones (confirmed by Kruskal-Wallis tests for all sediment strata) and the variation of bacterial densities depended more on sampling-site location across Lake Remoray. 
Gene-based potential methanogenesis ( $\mathrm{mcr} A / 16 \mathrm{~S}$ rRNA genes ratio) and methanotrophy ( $\mathrm{pmoA} / 16 \mathrm{~S}$ rRNA genes ratio) (Fig. 4b and 4c) varied depending on sampling-site location across Lake Remoray. There were no significant differences between littoral and profundal zones, except $p m o A / 16 S$ rRNA genes ratio which was significantly higher in the 2 -cm stratum of littoral-zone sediment cores. The microbial community had 700 -fold higher methanogenesis potential than methanotrophy potential. The highest methanogenesis potential was found for profundal-zone site \#1440 (average $\mathrm{mcrA} / 16$ ratio of 0.31 over the whole sediment core) and for littoral-zone sampling site \#1398 (average $m c r A / 16$ ratio of 0.34 over the whole sediment core). The lowest methanogenesis potential was found for littoral-zone sampling sites \#1413 and \#1414 (average $\mathrm{mcrA} / 16 \mathrm{~S}$ rRNA genes ratio of 0.09 and 0.08 , respectively, over the whole sediment core).

Archaeal and bacterial, and methanogen community structure across Lake Remoray

The high-throughput 16S rRNA gene sequencing approach applied here generated 3,788,355 quality sequences and recovered 1566 OTUs affiliated to both the Archaea and Bacteria domains.

NMDS analysis of the full archaeal and bacterial sequence dataset highlighted a distinct difference in sediment community structure between littoral and profundal zones (Fig. 5a) (ADONIS test, $R^{2}=0.13$, $\mathrm{P}=0.001)$. This difference was associated with different taxonomic compositions: Proteobacteria, Bacteroidetes, Planctomycetes, Acidobacteria and Chloroflexi were more abundant in the profundal zone whereas Cyanobacteria, Spirochaetes and Euryarchaeota were more abundant in the littoral zone of Lake Remoray. There was no effect of sampling depth along the sediment cores on microbial structure (ADONIS tests; $\mathrm{R}^{2}=0.10, \mathrm{P}=0.911$ ).

Based on the taxonomic classification in the 16S rRNA gene sequences dataset, we identified 41 OTUs affiliated to the methanogens group, representing $6.11 \%$ of the total sequences. NMDS analysis of methanogen-sequences dataset revealed two distinct groups on the ordination plot (Fig. 5b). The first group was represented by sediment cores collected in the tributaries area, and the second group clustered the sediment cores from all other sampling sites across the lake. ADONIS tests showed a significant effect of sampling depth between littoral and profundal zones $\left(R^{2}=0.22, P=0.001\right)$ and no significant effect of sampling depth along the sediment cores $\left(R^{2}=0.03, P=0.999\right)$ on methanogen community structure.

DESeq2 analysis on the 41 methanogen OTUs identified methanogen genera accounting for the differences between littoral and profundal zones (Fig. 6). Profundal-zone sediments had a higher relative abundance of OTUs affiliated to Methanomicrobiales order ( $81 \%$ of methanogen sequences) compared to littoral zone (65\% of methanogen sequences). Sediments in the littoral zone had a two-time higher relative abundance of OTUs affiliated to Candidatus Methanoperedens, C. Methanomethylicus and the Methanosaeta genus.

Linking methanogen communities and $\mathrm{CH}_{4}$-cycling parameters across Lake Remoray 
The methanogen community co-occurrence network was built based on pairwise correlations between the 41 OTUs affiliated to methanogens. The co-occurrence pattern within the methanogen community was determined by only keeping significant Pearson's correlations. The resulting network (Fig. 7a and b) was composed of 131 edges (all edges were positive correlations) representing $15 \%$ of possible withinnetwork connections (network density). The topological network parameters were: average degree $=6.4$, diameter $=6$, modularity $=0.48$, transitivity $=0.73$, average path length $=2.46$.

Covariation similarity analysis between methanogen OTUs showed 5 distinct modules within methanogen network and containing more than three OTUs (Fig. 7b). Analysis of the proportion of methanogen OTUs composing the network modules of Lake Remoray (Fig. 7c) showed that the methanogen OTUs of modules 1 and 2 were dominant in sediments close to the lake tributaries. The methanogens of module 5 dominated the profundal zones while the OTUs of module 3 were more abundant in littoral zones. The methanogens composing module 4 were found specifically in profundal zones, especially in the deepest sediment of Lake Remoray.

Analysis of module-functional parameter relationships based on the 100 samples collected from the 10 sample cores (Fig. 7d) revealed that sub-communities of modules 1 and 2 were only significantly correlated to OM concentration, whereas modules 3 and 4 (representing the largest methanogen subcommunities) were negatively correlated to $\mathrm{OM}$ and significantly positively correlated to $\mathrm{CH}_{4}$ concentration and functional methanogenesis potential. Methane production in Lake Remoray was significantly correlated to the abundance of module-3 and module-4 sub-communities.

\section{Discussion}

Lake Remoray presents long periods of hypoxia in the deepest part of the water column [28] due to an excess of autochthonous material deposition driven by primary overproduction and, to a lesser extent, to organic material inputs carried by its two tributaries (Tardy et al., In press). Methanogen species affiliated to the Methanomicrobia class were shown to be widely distributed in the surficial sediment layers of lake Remoray deepest parts (Tardy et al., In press), allowing to expect methane production in the sediment and methane diffusion along the water column, at least during periods of hypoxia. The aim of this study was to characterize the spatial variation of methane production across Lake Remoray sediment during the summer period, when dissolved oxygen levels decrease sharply with depth in the water column. Due to seasonally anoxic periods in profundal sediment and differences in OM content and quality, our main hypotheses were that it would select for specific and more abundant methanogen communities within the sediment microbial assemblages, and that methane production potential would increase from the littoral zone to the deepest zone of Lake Remoray.

Spatial heterogeneity of methane production and concentration across Lake Remoray

Both methane production potential and methane concentration were more related to sampling-site location than to water depth of the collected sediment cores. Similar or even higher potential methane 
production rates were recorded in sediment collected in the littoral zone (close to the farm and outlet) than in sediments collected in the deeper zones, with the exception of littoral-zone sampling sites located in the tributary plumes that had the lowest values for methane production potential.

The literature shows that methane production rates depend on the amount, nature and composition of OM inputs [20,53-55]. In a controlled experiment, West et al. (2012) found higher methane production rates following algal biomass input than terrestrial carbon addition whereas methanogenesis potential was similar between conditions. Duc et al. (2010) studied sediments of 8 boreal and temperate northern lakes and found higher methane production rates in sediments characterized by a $\mathrm{C}: \mathrm{N}$ ratio below 10 , whatever the different incubation temperatures tested. In Lake Remoray, sediment had a higher C:N ratio (average $\mathrm{C}: \mathrm{N}$ ratio=12) in the tributary area than in any other location of the lake (average $\mathrm{C}: \mathrm{N}$ ratio=8) (Tardy et al., In press).

As previously observed $[57,58]$, methane production potential was higher in the top layers of the

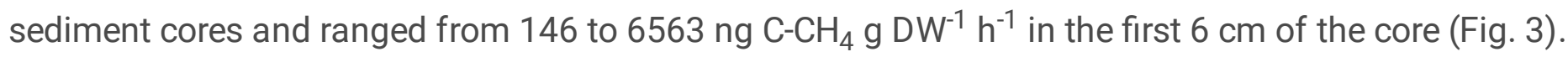
Methane production potential measured in Lake Remoray spanned a higher range than rates measured in Lake Onego (0-456 ng C- $\mathrm{CH}_{4} \mathrm{~g} \mathrm{DW}^{-1} \mathrm{~h}^{-1}$; Thomas et al., 2018), Lake Dago (1201-4203 ng C- $\mathrm{CH}_{4} \mathrm{~g} \mathrm{DW}^{-1}$ $\mathrm{h}^{-1}$; Chan et al., 2005) and Swedish lakes (24-1996 ng C- $\mathrm{CH}_{4} \mathrm{~g} \mathrm{DW}^{-1} \mathrm{~h}^{-1}$; Duc et al., 2010). However, these values should be interpreted with care, as potential production rates were estimated using different laboratory incubation temperatures $\left(20^{\circ} \mathrm{C}\right.$ here, $4^{\circ} \mathrm{C}$ in Thomas et al., $2018,10^{\circ} \mathrm{C}$ in Chan et al., 2005 , and $4^{\circ} \mathrm{C}, 10^{\circ} \mathrm{C}, 20^{\circ} \mathrm{C}$ and $30^{\circ} \mathrm{C}$ in Duc et al., 2010). Even though the incubation times used here were short (5 hrs), methane production is still temperature-dependent $[5,59,60]$ and this could have influenced the values obtained. However, the incubation temperature used here was chosen to reflect the temperature recorded at the sampling site in the shallower areas $\left(21.7^{\circ} \mathrm{C}\right)$ of the lake.

The highest potential methane production rates were in the sediment top layers. However, the methane concentrations measured in situ in the sediment core layers increased with distance from the watersediment interface at every sampling location. This could be related to (i) sub-favourable in situ conditions for methanogenesis, likely related to oxygen concentration or redox potential, and/or to (ii) methane loss from sediment to water column though either oxidation or emission, or both. Conceptual models based on methane concentration vs. depth curves could help to estimate the balance between oxidation and emission [61], but they are only qualitative and remain difficult to interpret. The analysis of the carbon isotopic signature of methane would have helped to quantify the contribution of $\mathrm{CH}_{4}$ oxidation [19] to diffusion mitigation. Methane oxidation can occur under both aerobic and anaerobic conditions, and is a metabolic pathway supported by both archaeal and bacterial microbial species [12]. Here, aerobic methanotrophy community abundance, assessed by quantifying relative abundance of the pmoA gene, represented only $0.01 \%$ to $0.03 \%$ of the sediment bacterial community. Although only sparsely represented, aerobic methanotrophs have very efficient enzymatic activities and can oxidize significant amounts of methane even at low populations densities (Mayr et al. 2020a; 2020b; Reis et al., 2020). However, as oxygen diffusion in the sediment compartment is expected to be low, aerobic 
methane oxidation may not be the only pathway involved in Lake Remoray, especially in the deeper area of the lake and/or deeper layers of the sediment column, even though methanotrophs are also active in anoxic conditions [65]. Anaerobic oxidation of methane is coupled with nitrate, sulphate or iron reduction [12]. The occurrence of the anaerobic methanotrophs $\mathrm{Ca}$. Methanoperedens-related sequences suggests that the anaerobic oxidation of methane using nitrate as terminal electron acceptor via the reverse methanogenesis pathway [66] could take place in Lake Remoray, as previously described in other lakes $[17,67]$. Further studies, based both on pore-water chemistry and carbon isotopic signature of $\mathrm{CH}_{4}$, are needed to better estimate how different oxidation pathways contribute to methane emission mitigation.

In Lake Remoray, methane diffusion from the sediment compartment to the water column varied according to sampling depth, ranging from $50-200 \mathrm{mg} \mathrm{CH}_{4} \mathrm{~m}^{-2} \mathrm{~d}^{-1}$ in profundal and littoral sampling points close to the farm, outlet and campsite. These methane diffusion figures are higher than previously reported for Lake Geneva (up to $37 \mathrm{mg} \mathrm{CH}_{4} \mathrm{~m}^{-2} \mathrm{~d}^{-1}$; Sollberger et al., 2014), Lake Stechlin (up to $39 \mathrm{mg}$ $\mathrm{CH}_{4} \mathrm{~m}^{-2} \mathrm{~d}^{-1}$; Li et al., 2020) and Lake Onego (up to $95 \mathrm{mg} \mathrm{CH}_{4} \mathrm{~m}^{-2} \mathrm{~d}^{-1}$; Thomas et al., 2018) but consistent with values reported for Lake Soppensee (up to $253 \mathrm{mg} \mathrm{CH}_{4} \mathrm{~m}^{-2} \mathrm{~d}^{-1}$; Vachon et al., 2019). This confirms the large contribution of the sediment compartment of Lake Remoray to the methane cycle. However, methane concentration and diffusion were measured during the summer oxygen depletion period and would probably be even higher in late fall when stronger hypoxia/anoxia prevails in the hypolimnion.

Taken together, our results argue against our main hypothesis and also highlight the significant contribution of littoral areas to methane production in this lake system. Previous studies have reported higher methane production in littoral zones relative to profundal-zone sediment [70-72]. This finding has important implications, since global estimations of methane emission from lake ecosystems are mainly based on a single measurement carried out in the deep areas of lakes [9, 73-75].

Spatial variation of sediment archaeal and bacterial, and methanogen communities

As observed in other freshwater lake ecosystems, water depth significantly affected sediment archaeal and bacterial community composition [76-79]. Littoral-zone sediment was dominated by Cyanobacteria species (29.7\% of total sequences) while profundal-zone sediment was dominated by Proteobacteria, Bacteroidetes, and Chloroflexi (25.4, 21.2 and $10.5 \%$ of total sequences, respectively). There was no significant effect of in-core stratum depth on archaeal and bacterial structure and composition. This finding contrasts with numerous studies showing a vertical structuration of bacterial and archaeal communities with the sediment depth in lake ecosystems [80-85]. In these studies, archaeal and bacterial composition changes were associated with different patterns of variation in chemical properties along the sediment depth, such as OM quality, oxygen concentration or redox potential. The lack of vertical structuration of sediment archaeal and bacterial communities found here suggests that chemical properties in the first 10 centimetres of the sediment compartment are relatively homogeneous. 
Based on the taxonomic affiliation in the 16S rRNA gene sequences dataset, we identified 41 OTUs affiliated to archaea involved in the methanogenesis function. The relative abundance of methanogen sequences varied from 1 to $17 \%$ according to location and in-core sediment depth. A large proportion of sequences was affiliated to Methanoregula (67\% of total methanogen sequences). Methanoregula is a hydrogenotrophic genus able to reduce $\mathrm{CO}_{2}$ with hydrogen as electron donor, and it has already been reported as predominant in many freshwater lakes (Borrel et al., 2011; Wen et al., 2017; Biderre-Petit et al., 2019; Berberich et al., 2020). The second most abundant methanogen was Methanosaeta (15\% of total methanogen sequences), an acetotrophic genus able to produce methane with acetate as final electron donor [88]. Based on the DNA abundance ratio of these two methanogenic populations in sediment, it suggests that methanogenesis in Lake Remoray results mainly from the hydrogenotrophic pathway and to a lesser extent the acetoclastic pathway, but this would require to be confirmed by activity measurements. A previous study suggested that the hydrogenotrophic pathway outcompetes the acetoclastic pathway in lake sediment if OM is recalcitrant [58].

Methanosaeta was the more abundant methanogen in the littoral zone whereas species affiliated to Methanomicrobiales and Methanofastidiosales were the more abundant methanogen in profundal sediments. Littoral sediments located in the tributary area had a specific methanogen composition. In this part of lake, the methanogen community was largely associated to OTUs affiliated to Methanobacterium and Methanosarcina, highlighting the significant horizontal structuration of the methanogen community at the whole-lake scale. A few studies have characterized the horizontal distribution of sediment methanogen communities within a single lake ecosystem. Only Berberich et al. (2020) in Lake Harsha showed large variation in methanogen community composition and structure between riverine, lacustrine and transitional areas of the lake, as well as a higher proportion of Methanosarcina species in the riverine zone.

To go further in the characterization of the methanogen communities, a co-occurrence network was built from the 41 OTUs detected in all sediment samples. The resulting methanogenic network highlighted exclusively positive relationships between the different OTUs, suggesting the absence of competition and the predominance of facilitative interactions within the sediment methanogen community of Lake Remoray. The other interesting metric from the methanogen network is modularity, which was positive and high enough $(\mathrm{Q}=0.48)$ to point to the possible presence of community structures (or 'modules') within the network [89]. In biotic co-occurrence networks, the presence of sub communities is usually related to the heterogeneity of habitat and to the diversification of ecological niches in the studied ecosystem [90, 91]. Our analysis in Lake Remoray sediment found 5 distinct methanogen sub communities (modules) in which interactions are more frequent than with the rest of the community. Two of these sub communities were particularly large (modules 3 and 5; Fig. 7) and both grouped the interactions between OTUs affiliated to Methanoregula, Methanolinea, Methanosaeta and Methanomassiliicoccales species. Three other smaller sub communities (module 1, 2 and 4) were identified with specific taxonomic compositions. Consistently with methanogen community structure and composition, the abundance of sub communities varied according to sampling location in Lake Remoray. Two specific methanogen sub 
communities were found exclusively in the sediment of the deeper area (module 4) and sediments close to tributaries (module 1), thus further confirming the existence of diverse methanogen niches across Lake Remoray sediment and again highlighting the need to integrate lake-scale characterization of methanogen communities when assessing lake methane emissions.

Linking spatial variation of methanogen communities to methane production rate in Lake Remoray

Analysis of module structure in the co-occurrence network can also provide substantial information on the functional and ecological properties of various ecosystems [90]. For instance, numerous studies have used module structure to explain the influences of environmental parameters on microbial community structure in lake ecosystems [92-96]. Functional relationships between modules showed that the amount of $\mathrm{OM}$ in the sediments was a key factor of variation in abundance of methanogenic sub communities, influencing four modules of the network. The quantity and quality of sediment $\mathrm{OM}$ are now well recognized as significant drivers of variation in sediment methanogen communities, shaping abundance, genetic structure and taxonomic composition $[53,82,97]$. In Lake Remoray, higher sediment OM content positively influenced modules 1 and 2 , which are more abundant in sediments close to tributaries. As described in section 4.1, sediment OM content and $\mathrm{C}: \mathrm{N}$ ratio are higher in this part of lake, mainly due to allochthonous $\mathrm{OM}$ deposition by tributaries. Conversely, modules 3 and 5 were negatively influenced by sediment $\mathrm{OM}$ content and their large abundances were associated to autochthonous OM depositions characterized by lower $\mathrm{C}: \mathrm{N}$ ratio and related to the lake's high primary production. Taken together, these results suggest that the origin (allochthonous vs. autochthonous) and quantity of OM deposition in Lake Remoray sediment has led to a diversification of ecological niches for the methanogenic community.

The two larger modules (modules 3 and 5) were positively associated to methanogenesis potential and sediment methane concentration, suggesting that the methane production of Lake Remoray is mainly carried out by the biotic interactions between methanogen taxa composing these two sub communities. However, only one of these modules was positively associated to methane production rate. On the other hand, the smaller methanogen sub community in the network (module 3) represented by the interactions between three methanogen taxa (Methanolinea, Methanofastidiosales and Methanospirillum) was strongly associated to methane production rate. This suggests that in the deeper part of Lake Remoray, methane production intensity depends mainly on the activity of a handful of methanogen species. However, this interpretation warrants caution, as production rates were estimated as a methane potential measured under controlled in-lab conditions. The absence of any strong relationship between modules 3 and 5 and methane production rate could be due to the experimental approach used. The relationship between variation in abundance of methanogenic communities and methane production rate in lake sediment is difficult to explore [97]. Indeed, methane production rate does not rely solely on the presence and abundance of methanogenic species, and several environmental parameters also have to be factored in, such as $\mathrm{OM}$ composition, temperature, ion content (i.e. $\mathrm{SO}_{4}{ }^{2-}, \mathrm{Fe}^{3+}, \mathrm{NO}_{2}{ }^{-}, \mathrm{NO}_{3}{ }^{-}$) and $\mathrm{pH}[5,8,13,97]$.

\section{Conclusion}


Methane production and methanogenesis potential in sediments were expected to be higher in profundal areas of the lake where annual hypoxia occurs during the late summer-winter period, but we found that some littoral zones contribute as much or more to methane diffusion along the water column. Spatial patterns of methane concentration and production potential were associated with variations in nature and quality of sediment organic matter and the presence of specific methanogenic sub communities. Taken together, these results emphasize the importance of integrating the whole lake scale (i.e. both sediment and water column, from littoral zone to the deepest parts, including riverine zones) in order to better gauge the contribution of lake ecosystems to global methane emissions. Temporal scale is also an important factor, especially for lakes that exhibit seasonal anoxic conditions in bottom water. Further studies are needed to address the sediment-to-water column continuum and improve our predictions of methane emission from lakes. Combining molecular and geochemistry approaches with powerful isotopic approaches could valuably integrate both the spatial and temporal scales.

\section{Statements And Declarations}

\section{Funding}

The authors did not receive support from any organization for the submitted work.

\section{Conflicts of interest}

The authors have no conflicts of interests to declare that are relevant to the content of this article.

\section{Ethics approval}

No approval of research ethics committees was required to accomplish the goals of this study because experimental work was conducted with sediment microbial species.

\section{Availability of data and material}

The datasets generated during and/or analysed during the current study are available from the corresponding author on reasonable request.

\section{Code availability}

Codes for statistical analysis used in this study are available from the corresponding author on reasonable request.

\section{Authors' contributions}

David Etienne, Laurent Millet and Emilie Lyautey contributed to the study conception and design. Material preparation and data collection were performed by David Etienne and Emilie Lyautey. Biostatistical analyses were performed by Vincent Tardy. Vincent Tardy and Emilie Lyautey drafted the manuscript. All authors read and approved the final manuscript. 


\section{References}

1. IPCC (2007) Climate Change 2007: The Physical Science Basis. Contribution of Working Group I to the Fourth Assessment Report of the Intergovernmental Panel on Climate Change

2. Nisbet EG, Manning MR, Dlugokencky EJ, et al (2019) Very strong atmospheric methane growth in the 4 Years 2014-2017: implications for the Paris Agreement. Global Biogeochem Cycles 33:318-342. https://doi.org/10.1029/2018GB006009

3. Bastviken D, Cole J, Pace M, Tranvik L (2004) Methane emissions from lakes: Dependence of lake characteristics, two regional assessments, and a global estimate. Global Biogeochem Cycles 18:1-12. https://doi.org/10.1029/2004GB002238

4. Saunois M, Bousquet P, Poulter B, et al (2016) The global methane budget 2000-2012. Earth Syst Sci Data 8:697-751. https://doi.org/10.5194/essd-8-697-2016

5. Fuchs A, Lyautey E, Montuelle B, Casper $P$ (2016) Effects of increasing temperatures on methane concentrations and methanogenesis during experimental incubation of sediments from oligotrophic and mesotrophic lakes. J Geophys Res Biogeosciences 121:1394-1406.

https://doi.org/10.1002/2016JG003328

6. Cavicchioli R, Ripple WJ, Timmis KN, et al (2019) Scientists' warning to humanity: microorganisms and climate change. Nat Rev Microbiol 17:569-586. https://doi.org/10.1038/s41579-019-0222-5

7. Beaulieu JJ, DelSontro T, Downing JA (2019) Eutrophication will increase methane emissions from lakes and impoundments during the 21st century. Nat Commun 10:3-7. https://doi.org/10.1038/s41467019-09100-5

8. Evans PN, Boyd JA, Leu AO, et al (2019) An evolving view of methane metabolism in the Archaea. Nat Rev Microbiol 17:219-232. https://doi.org/10.1038/s41579-018-0136-7

9. Bastviken D, Cole JJ, Pace ML, Van de-Bogert MC (2008) Fates of methane from different lake habitats: Connecting whole-lake budgets and CH4 emissions. J Geophys Res Biogeosciences 113:1-13. https://doi.org/10.1029/2007JG000608

10. Bhattarai S, Cassarini C, Lens PNL (2019) Physiology and distribution of archaeal methanotrophs that couple anaerobic oxidation of methane with sulfate reduction. Microbiol Mol Biol Rev 83:9-62. https://doi.org/10.1128/MMBR.00074-18

11. Kang CS, Dunfield PF, Semrau JD (2019) The origin of aerobic methanotrophy within the Proteobacteria. FEMS Microbiol Lett 366:1-11. https://doi.org/10.1093/femsle/fnz096

12. Lehours A-C, Borrel G, Morel-Desrosiers N, et al (2016) Anaerobic Microbial Communities and Processes Involved in the Methane Cycle in Freshwater Lakes-a Focus on Lake Pavin. In: Sime-Ngando T, 
Boivin P, Chapron E, et al (eds) Lake Pavin. Springer International Publishing, Cham, pp 255-284

13. Borrel G, Jézéquel D, Biderre-Petit C, et al (2011) Production and consumption of methane in freshwater lake ecosystems. Res Microbiol 162:832-847. https://doi.org/10.1016/j.resmic.2011.06.004

14. Froelich PN, Klinkhammer GP, Bender ML, et al (1979) Early oxidation of organic matter in pelagic sediments of the eastern equatorial Atlantic: suboxic diagenesis. Geochim Cosmochim Acta 43:10751090. https://doi.org/10.1016/0016-7037(79)90095-4

15. Chaudhary PP, Brablcová L, Buriánková I, Rulík M (2013) Molecular diversity and tools for deciphering the methanogen community structure and diversity in freshwater sediments. Appl Microbiol Biotechnol 97:7553-7562. https://doi.org/10.1007/s00253-013-5102-8

16. Chowdhury TR, Dick RP (2013) Ecology of aerobic methanotrophs in controlling methane fluxes from wetlands. Appl Soil Ecol 65:8-22. https://doi.org/10.1016/j.apsoil.2012.12.014

17. Thomas C, Frossard V, Perga ME, et al (2018) Lateral variations and vertical structure of the microbial methane cycle in the sediment of Lake Onego (Russia). Inl Waters 0:1-22.

https://doi.org/10.1080/20442041.2018.1500227

18. Semrau JD, Dispirito AA, Yoon S (2010) Methanotrophs and copper. FEMS Microbiol Rev 34:496-531. https://doi.org/10.1111/j.1574-6976.2010.00212.x

19. Bastviken D, Ejlertsson J, Tranvik L (2002) Measurement of methane oxidation in lakes: A comparison of methods. Environ Sci Technol 36:3354-3361. https://doi.org/10.1021/es010311p

20. Duc NT, Crill P, Bastviken D (2010) Implications of temperature and sediment characteristics on methane formation and oxidation in lake sediments. Biogeochemistry 100:185-196.

https://doi.org/10.1007/s10533-010-9415-8

21. Bosse U, Frenzel P, Conrad R (1993) Inhibition of methane oxidation by ammonium in the surface layer of a littoral sediment. FEMS Microbiol Ecol 13:123-134. https://doi.org/10.1016/01686496(93)90030-B

22. Murase J, Frenzel $P$ (2008) Selective grazing of methanotrophs by protozoa in a rice field soil. FEMS Microbiol Ecol 65:408-414. https://doi.org/10.1111/j.1574-6941.2008.00511.x

23. Lehours AC, Bardot C, Thenot A, et al (2005) Anaerobic microbial communities in Lake Pavin, a unique meromictic lake in France. Appl Environ Microbiol 71:7389-7400.

https://doi.org/10.1128/AEM.71.11.7389-7400.2005

24. Deemer BR, Harrison JA (2019) Summer redox dynamics in a eutrophic reservoir and sensitivity to a summer's end drawdown event. Ecosystems 22:1618-1632. https://doi.org/10.1007/s10021-019-003620 
25. Butcher JB, Nover D, Johnson TE, Clark CM (2015) Sensitivity of lake thermal and mixing dynamics to climate change. Clim Change 129:295-305. https://doi.org/10.1007/s10584-015-1326-1

26. Sahoo GB, Forrest AL, Schladow SG, et al (2016) Climate change impacts on lake thermal dynamics and ecosystem vulnerabilities. Limnol Oceanogr 61:496-507. https://doi.org/10.1002/Ino.10228

27. Jenny JP, Anneville O, Arnaud F, et al (2020) Scientists' Warning to Humanity: Rapid degradation of the world's large lakes. J Great Lakes Res 46:686-702. https://doi.org/10.1016/j.jglr.2020.05.006

28. Belle S, Millet L, Verneaux V, et al (2016) 20Th century human pressures drive reductions in deepwater oxygen leading to losses of benthic methane-based food webs. Quat Sci Rev 137:209-220. https://doi.org/10.1016/j.quascirev.2016.02.019

29. Belle S, Baudrot V, Lami A, et al (2017) Rising variance and abrupt shifts of subfossil chironomids due to eutrophication in a deep sub-alpine lake. Aquat Ecol 51:307-319. https://doi.org/10.1007/s10452-0179618-3

30. Heiri O, Lotter AF, Lemcke G (2001) Loss on ignition as a method for estimating organic and carbonate content in sediments: Reproducibility and comparability of results. J Paleolimnol 25:101-110. https://doi.org/10.1023/A:1008119611481

31. Avnimelech Y, Ritvo G, Meijer LE, Kochba M (2001) Water content, organic carbon and dry bulk density in flooded sediments. Aquac Eng 25:25-33. https://doi.org/10.1016/S0144-8609(01)00068-1

32. Maerki M, Wehrli B, Dinkel C, Müller B (2004) The influence of tortuosity on molecular diffusion in freshwater sediments of high porosity. Geochim Cosmochim Acta 68:1519-1528.

https://doi.org/10.1016/j.gca.2003.09.019

33. Lerman A (1979) Geochemical processes. Water and sediment environments. John Wiley and Sons, Inc., New York

34. Sollberger S, Corella JP, Girardclos S, et al (2014) Spatial heterogeneity of benthic methane dynamics in the subaquatic canyons of the Rhone River Delta (Lake Geneva). Aquat Sci 76:89-101. https://doi.org/10.1007/s00027-013-0319-2

35. López-Gutiérrez JC, Henry S, Hallet S, et al (2004) Quantification of a novel group of nitrate-reducing bacteria in the environment by real-time PCR. J Microbiol Methods 57:399-407. https://doi.org/10.1016/j.mimet.2004.02.009

36. Hales BA, Edwards C, Ritchie DA, et al (1996) Isolation and identification of methanogen-specific DNA from blanket bog peat by PCR amplification and sequence analysis. Appl Environ Microbiol 62:668-675. https://doi.org/10.1128/aem.62.2.668-675.1996 
37. Bourne DG, McDonald IR, Murrell JC (2001) Comparison of pmoA PCR primer sets as tools for investigating methanotroph diversity in three Danish soils. Appl Environ Microbiol 67:3802-3809. https://doi.org/10.1128/AEM.67.9.3802-3809.2001

38. Freitag TE, Prosser JI (2009) Correlation of methane production and functional gene transcriptional activity in a peat soil. Appl Environ Microbiol 75:6679-6687. https://doi.org/10.1128/AEM.01021-09

39. Stolyar S, Costello AM, Peeples TL, Lidstrom ME (1999) Role of multiple gene copies in particulate methane monooxygenase activity in the methane-oxidizing bacterium Methylococcus capsulatus Bath. Microbiology 145:1235-1244. https://doi.org/10.1099/13500872-145-5-1235

40. Wang Y, Qian PY (2009) Conservative fragments in bacterial 16S rRNA genes and primer design for $16 \mathrm{~S}$ ribosomal DNA amplicons in metagenomic studies. PLoS One 4:.

https://doi.org/10.1371/journal.pone.0007401

41. Kozich JJ, Westcott SL, Baxter NT, et al (2013) Development of a dual-index sequencing strategy and curation pipeline for analyzing amplicon sequence data on the miseq illumina sequencing platform. Appl Environ Microbiol 79:5112-5120. https://doi.org/10.1128/AEM.01043-13

42. Bolger AM, Lohse M, Usadel B (2014) Trimmomatic: A flexible trimmer for Illumina sequence data. Bioinformatics 30:2114-2120. https://doi.org/10.1093/bioinformatics/btu170

43. Escudié F, Auer L, Bernard M, et al (2018) FROGS: Find, Rapidly, OTUs with Galaxy Solution. Bioinformatics 34:1287-1294. https://doi.org/10.1093/bioinformatics/btx791

44. Magoc T, Salzberg SL (2011) FLASH: Fast length adjustment of short reads to improve genome assemblies. Bioinformatics 27:2957-2963. https://doi.org/10.1093/bioinformatics/btr507

45. Mahé F, Rognes T, Quince C, et al (2014) Swarm: robust and fast clustering method for ampliconbased studies. PeerJ PeerJ 2:e5:1-13. https://doi.org/10.7717/peerj.593

46. Rognes T, Flouri T, Nichols B, et al (2016) VSEARCH: a versatile open source tool for metagenomics. PeerJ 4:e2584. https://doi.org/10.7717/peerj.2584

47. Quast C, Pruesse E, Yilmaz P, et al (2013) The SILVA ribosomal RNA gene database project: Improved data processing and web-based tools. Nucleic Acids Res 41:590-596.

https://doi.org/10.1093/nar/gks1219

48. Altschul SF, Gish W, Miller W, et al (1990) Basic local alignment search tool. J Mol Biol 215:403-410. https://doi.org/10.1016/S0022-2836(05)80360-2

49. Lozupone C, Knight R (2005) UniFrac: a New Phylogenetic Method for Comparing Microbial Communities. Appl Environ Microbiol 71:8228-8235. https://doi.org/10.1128/AEM.71.12.8228 
50. Love MI, Huber W, Anders S (2014) Moderated estimation of fold change and dispersion for RNA-seq data with DESeq2. Genome Biol 15:1-21. https://doi.org/10.1186/s13059-014-0550-8

51. Benjamini Y, Hochberg Y (1995) Controlling the false discovery rate - a practical and powerful approach to multiple testing. J R Stat Soc 57:289-300. https://doi.org/10.2307/2346101

52. Langfelder P, Horvath S (2008) WGCNA: An R package for weighted correlation network analysis. BMC Bioinformatics 9:. https://doi.org/10.1186/1471-2105-9-559

53. Berberich ME, Beaulieu JJ, Hamilton TL, et al (2020) Spatial variability of sediment methane production and methanogen communities within a eutrophic reservoir: Importance of organic matter source and quantity. Limnol Oceanogr 65:1336-1358. https://doi.org/10.1002/Ino.11392

54. Grasset C, Mendonça R, Villamor Saucedo G, et al (2018) Large but variable methane production in anoxic freshwater sediment upon addition of allochthonous and autochthonous organic matter. Limnol Oceanogr 63:1488-1501. https://doi.org/10.1002/Ino.10786

55. Bertolet BL, Olson CR, Szydlowski DK, et al (2020) Methane and primary productivity in lakes: divergence of temporal and spatial relationships. J Geophys Res Biogeosciences 125:1-10. https://doi.org/10.1029/2020JG005864

56. West WE, Coloso JJ, Jones SE (2012) Effects of algal and terrestrial carbon on methane production rates and methanogen community structure in a temperate lake sediment. Freshw Biol 57:949-955. https://doi.org/10.1111/j.1365-2427.2012.02755.x

57. Chan OC, Claus P, Casper P, et al (2005) Vertical distribution of structure and function of the methanogenic archaeal community in Lake Dagow sediment. Environ Microbiol 7:1139-1149. https://doi.org/10.1111/j.1462-2920.2005.00790.x

58. Liu Y, Conrad R, Yao T, et al (2017) Change of methane production pathway with sediment depth in a lake on the Tibetan plateau. Palaeogeogr Palaeoclimatol Palaeoecol 474:279-286. https://doi.org/10.1016/j.palaeo.2016.06.021

59. Schulz S, Matsuyama H, Conrad R (1997) Temperature dependence of methane production from different precursors in a profundal sediment (Lake Constance). FEMS Microbiol Ecol 22:207-213. https://doi.org/10.1111/j.1574-6941.1997.tb00372.x

60. Yvon-Durocher G, Allen AP, Bastviken D, et al (2014) Methane fluxes show consistent temperature dependence across microbial to ecosystem scales. Nature 507:488-491.

https://doi.org/10.1038/nature13164

61. Bernard BB (1979) Methane in marine sediments. Deep Sea Res Part A Oceanogr Res Pap 26:429443. https://doi.org/10.1016/0198-0149(79)90056-6 
62. Mayr MJ, Zimmermann M, Guggenheim C, et al (2020) Niche partitioning of methane-oxidizing bacteria along the oxygen-methane counter gradient of stratified lakes. ISME J 14:274-287. https://doi.org/10.1038/s41396-019-0515-8

63. Reis PCJ, Thottathil SD, Ruiz-González C, Prairie YT (2020) Niche separation within aerobic methanotrophic bacteria across lakes and its link to methane oxidation rates. Environ Microbiol 22:738751. https://doi.org/10.1111/1462-2920.14877

64. Mayr MJ, Zimmermann M, Dey J, et al (2020) Growth and rapid succession of methanotrophs effectively limit methane release during lake overturn. Commun Biol 3:1-9. https://doi.org/10.1038/s42003-020-0838-z

65. Oswald K, Milucka J, Brand A, et al (2016) Aerobic gammaproteobacterial methanotrophs mitigate methane emissions from oxic and anoxic lake waters. Limnol Oceanogr 61:S101-S118. https://doi.org/10.1002/Ino.10312

66. Haroon MF, Hu S, Shi Y, et al (2013) Anaerobic oxidation of methane coupled to nitrate reduction in a novel archaeal lineage. Nature 500:567-570. https://doi.org/10.1038/nature12375

67. Deutzmann JS, Stief P, Brandes J, Schink B (2014) Anaerobic methane oxidation coupled to denitrification is the dominant methane sink in a deep lake. Proc Natl Acad Sci U S A 111:18273-18278. https://doi.org/10.1073/pnas.1411617111

68. Li L, Fuchs A, Ortega SH, et al (2020) Spatial methane pattern in a deep freshwater lake: Relation to water depth and topography. Sci Total Environ. https://doi.org/10.1016/j.scitotenv.2020.142829

69. Vachon D, Langenegger T, Donis D, McGinnis DF (2019) Influence of water column stratification and mixing patterns on the fate of methane produced in deep sediments of a small eutrophic lake. Limnol Oceanogr 64:2114-2128. https://doi.org/10.1002/Ino.11172

70. Murase J, Sakai Y, Sugimoto A, et al (2003) Sources of dissolved methane in Lake Biwa. Limnology 4:91-99. https://doi.org/10.1007/s10201-003-0095-0

71. Hofmann H, Federwisch L, Peeters F (2010) Wave-induced release of methane: Littoral zones as a source of methane in lakes. Limnol Oceanogr 55:1990-2000. https://doi.org/10.4319/lo.2010.55.5.1990

72. Li L, Xue B, Yao S, et al (2018) Spatial-temporal patterns of methane dynamics in Lake Taihu. Hydrobiologia 822:143-156. https://doi.org/10.1007/s10750-018-3670-4

73. Rasilo T, Prairie YT, del Giorgio PA (2015) Large-scale patterns in summer diffusive $\mathrm{CH} 4$ fluxes across boreal lakes, and contribution to diffusive C emissions. Glob Chang Biol 21:1124-1139. https://doi.org/10.1111/gcb.12741 
74. West WE, Creamer KP, Jones SE (2016) Productivity and depth regulate lake contributions to atmospheric methane. Limnol Oceanogr 61:S51-S61. https://doi.org/10.1002/Ino.10247

75. Rinta P, Bastviken D, Schilder J, et al (2017) Higher late summer methane emission from central than Northern European lakes. J Limnol 76:52-67. https://doi.org/10.4081/jlimnol.2016.1475

76. Ruuskanen MO, St. Pierre KA, St. Louis VL, et al (2018) Physicochemical drivers of microbial community structure in sediments of Lake Hazen, Nunavut, Canada. Front Microbiol 9:1-16. https://doi.org/10.3389/fmicb.2018.01138

77. Wu K, Zhao W, Wang Q, et al (2019) The relative abundance of benthic bacterial phyla along a waterdepth gradient in a plateau lake: Physical, chemical, and biotic drivers. Front Microbiol 10:. https://doi.org/10.3389/fmicb.2019.01521

78. Zhang J, Yang Y, Zhao L, et al (2015) Distribution of sediment bacterial and archaeal communities in plateau freshwater lakes. Appl Microbiol Biotechnol 99:3291-3302. https://doi.org/10.1007/s00253-014$6262-x$

79. Zhang L, Zhao T, Shen T, Gao G (2019) Seasonal and spatial variation in the sediment bacterial community and diversity of Lake Bosten, China. J Basic Microbiol 59:224-233. https://doi.org/10.1002/jobm.201800452

80. Han X, Schubert CJ, Fiskal A, et al (2020) Eutrophication as a driver of microbial community structure in lake sediments. Environ Microbiol 22:3446-3462. https://doi.org/10.1111/1462-2920.15115

81. Xiong W, Xie P, Wang S, et al (2015) Sources of organic matter affect depth-related microbial community composition in sediments of Lake Erhai, Southwest China. J Limnol 74:310-323. https://doi.org/10.4081/jlimnol.2014.1106

82. Billard E, Domaizon I, Tissot N, et al (2015) Multi-scale phylogenetic heterogeneity of archaea, bacteria, methanogens and methanotrophs in lake sediments. Hydrobiologia 751:159-173. https://doi.org/10.1007/s10750-015-2184-6

83. Wurzbacher C, Fuchs A, Attermeyer K, et al (2017) Shifts among eukaryota, bacteria, and archaea define the vertical organization of a lake sediment. Microbiome 5:1-16. https://doi.org/10.1186/S40168017-0255-9

84. Rissanen AJ, Peura S, Mpamah PA, et al (2019) Vertical stratification of bacteria and archaea in sediments of a small boreal humic lake. FEMS Microbiol Lett 366:1-11. https://doi.org/10.1093/femsle/fnz044

85. Ding X, Peng XJ, Jin BS, et al (2015) Spatial distribution of bacterial communities driven by multiple environmental factors in a beach wetland of the largest freshwater lake in China. Front Microbiol 6:1-9. https://doi.org/10.3389/fmicb.2015.00129 
86. Wen X, Yang S, Horn F, et al (2017) Global biogeographic analysis of methanogenic archaea identifies community-shaping environmental factors of natural environments. Front Microbiol 8:1-13. https://doi.org/10.3389/fmicb.2017.01339

87. Biderre-Petit C, Taib N, Gardon H, et al (2019) New insights into the pelagic microorganisms involved in the methane cycle in the meromictic Lake Pavin through metagenomics. FEMS Microbiol Ecol 95:114. https://doi.org/10.1093/femsec/fiy183

88. Ferry JG (2010) The chemical biology of methanogenesis. Planet Space Sci 58:1775-1783. https://doi.org/10.1016/j.pss.2010.08.014

89. Newman MEJ (2006) Modularity and community structure in networks. Proc Natl Acad Sci U S A 103:8577-8582. https://doi.org/10.1073/pnas.0601602103

90. Barberán A, Bates ST, Casamayor EO, Fierer N (2012) Using network analysis to explore co-occurrence patterns in soil microbial communities. ISME J 6:343-351. https://doi.org/10.1038/ismej.2011.119

91. Ren Z, Niu D, Ma P, et al (2020) Bacterial communities in stream biofilms in a degrading grassland watershed on the Qinghai-Tibet Plateau. Front Microbiol 11:1-12.

https://doi.org/10.3389/fmicb.2020.01021

92. Ren Z, Wang F, Qu X, et al (2017) Taxonomic and functional differences between microbial communities in Qinghai Lake and its input streams. Front Microbiol 8:1-14. https://doi.org/10.3389/fmicb.2017.02319

93. Xu H, Zhao D, Huang R, et al (2018) Contrasting network features between free-living and particleattached bacterial communities in Taihu Lake. Microb Ecol 76:303-313. https://doi.org/10.1007/s00248017-1131-7

94. Zhao D, Shen F, Zeng J, et al (2016) Network analysis reveals seasonal variation of co-occurrence correlations between Cyanobacteria and other bacterioplankton. Sci Total Environ 573:817-825. https://doi.org/10.1016/j.scitotenv.2016.08.150

95. Capo E, Debroas D, Arnaud F, et al (2017) Tracking a century of changes in microbial eukaryotic diversity in lakes driven by nutrient enrichment and climate warming. Environ Microbiol 19:2873-2892. https://doi.org/10.1111/1462-2920.13815

96. Cao X, Zhao D, Xu H, et al (2018) Heterogeneity of interactions of microbial communities in regions of Taihu Lake with different nutrient loadings: A network analysis. Sci Rep 8:1-11.

https://doi.org/10.1038/s41598-018-27172-z

97. Bertolet BL, West WE, Armitage DW, Jones SE (2019) Organic matter supply and bacterial community composition predict methanogenesis rates in temperate lake sediments. Limnol Oceanogr Lett 4:164172. https://doi.org/10.1002/lol2.10114 
Figures

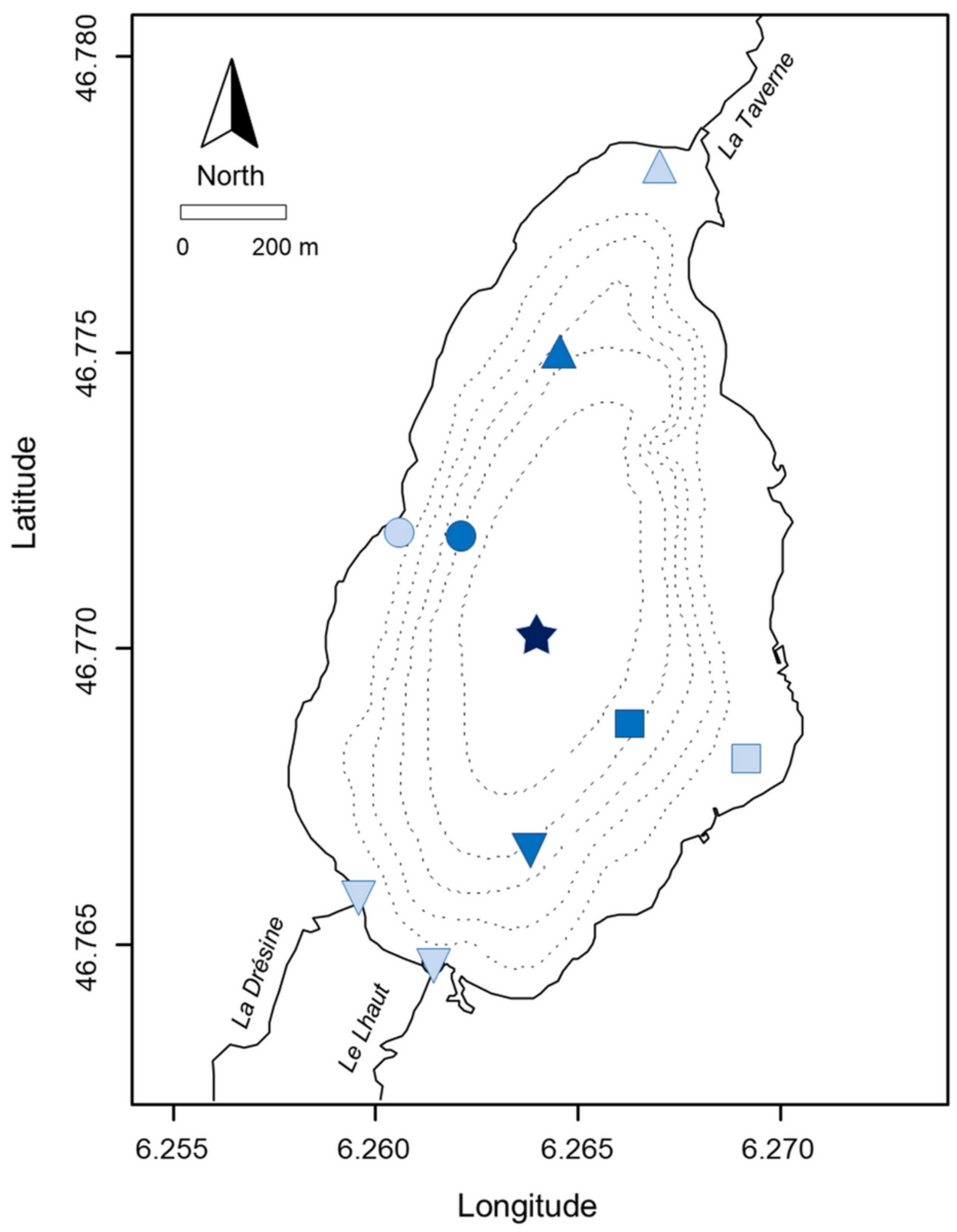

Figure 1

Map of Lake Remoray showing the sediment-core sampling points used in the year- 2017 campaign. Lake bathymetry is represented in dashed black lines showing 5-m-depth contours. 


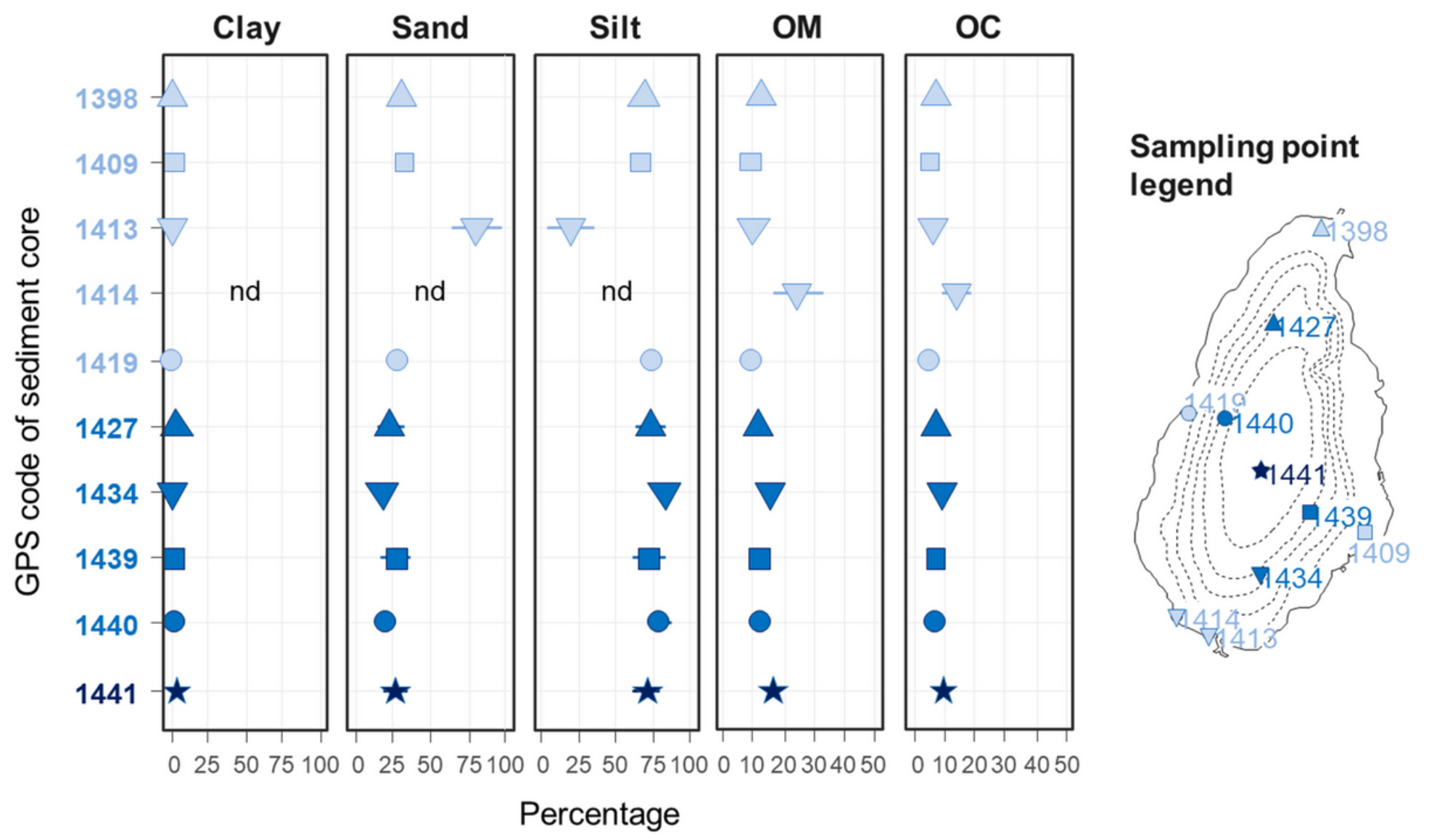

Figure 2

Sediment texture (percentage of clay, sand and silt) and percentage of organic matter (OM) and organic carbon $(\mathrm{OC})$ for each sediment core. Each symbol and line represents the average and standard deviation of the parameter measured every two $\mathrm{cm}$ along the first $10 \mathrm{~cm}$ of the sediment cores. 
(a)

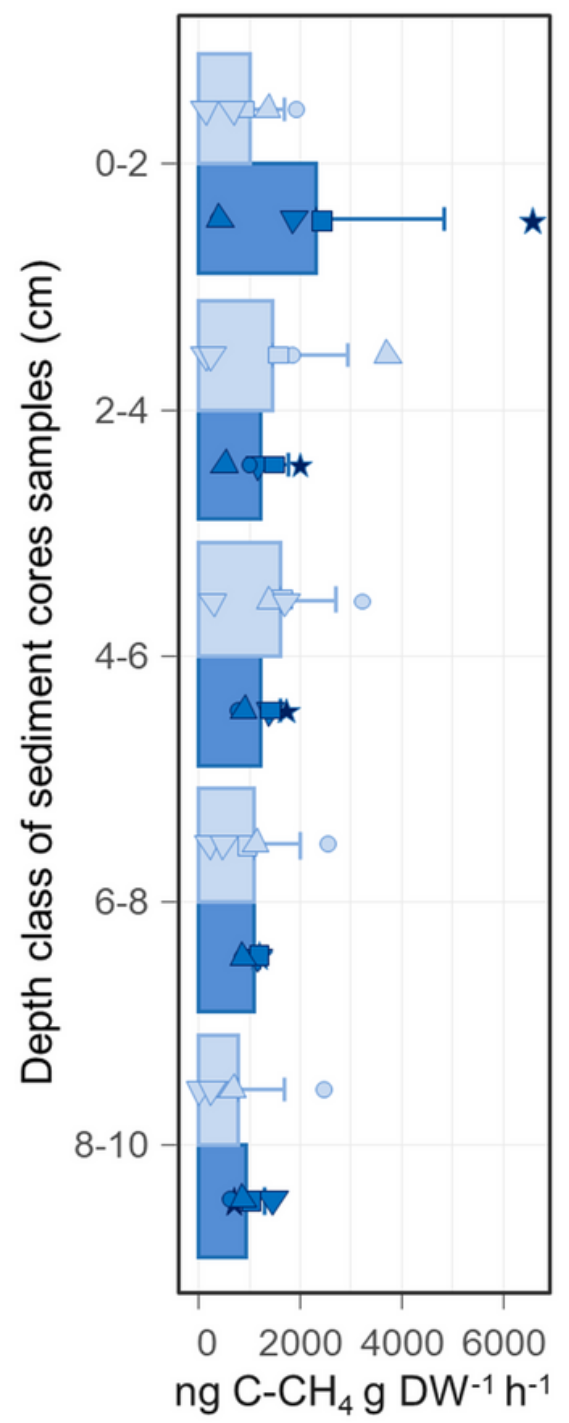

(b)

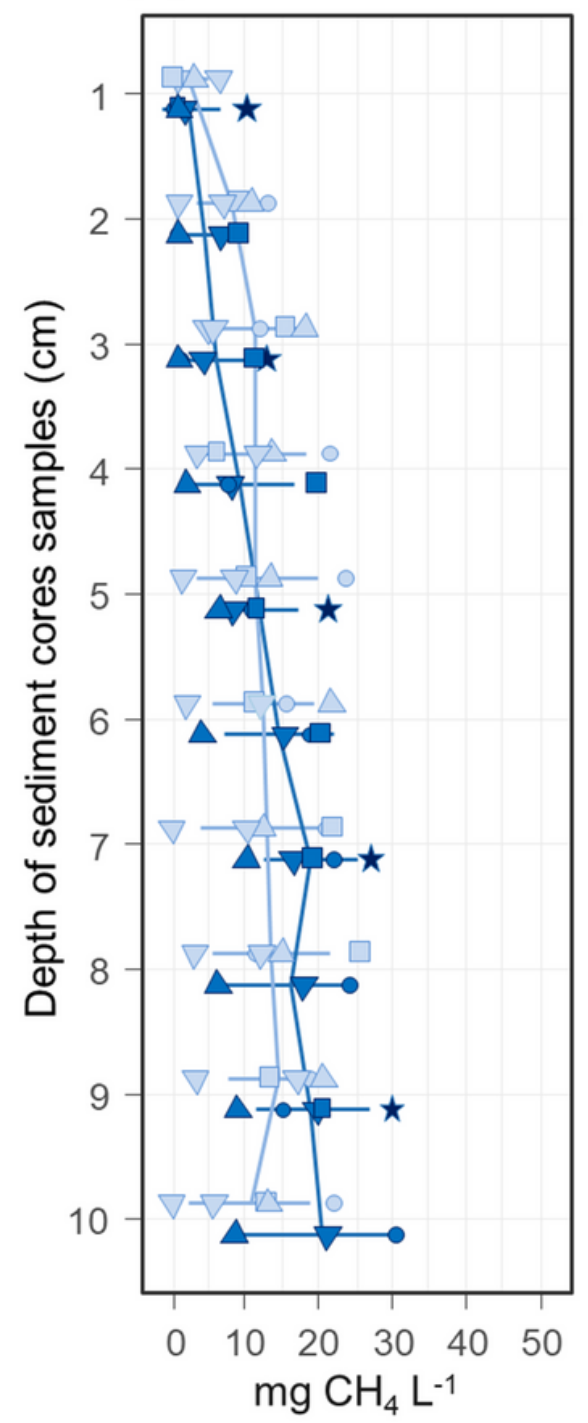

(c)
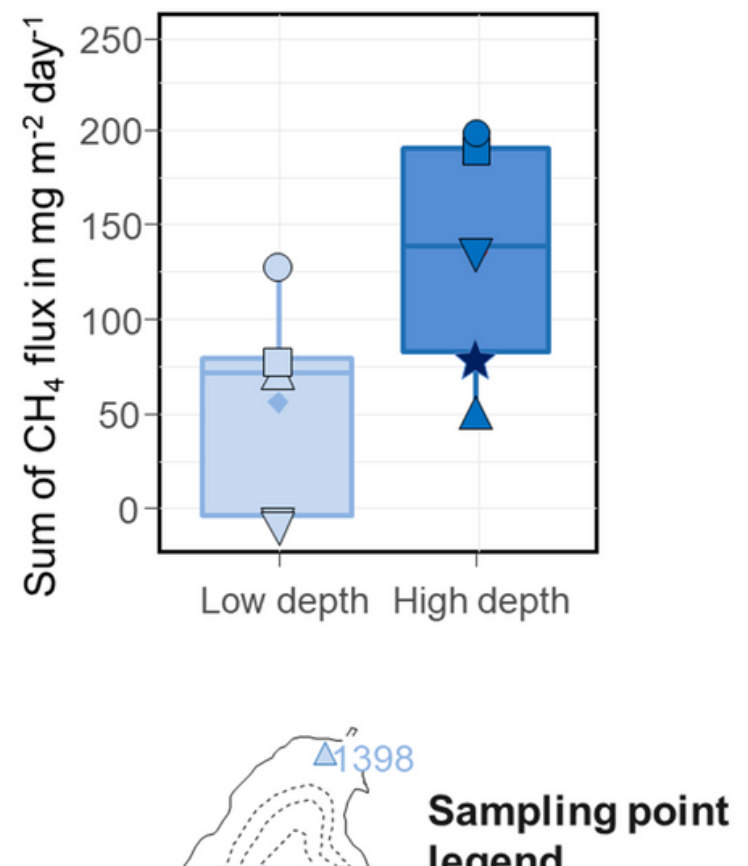
legend

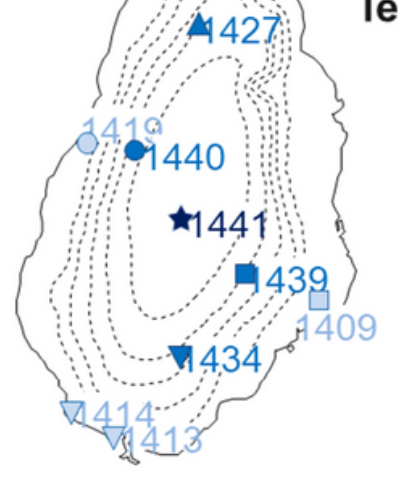

Figure 3

Average values for methane production potential (a), methane concentration (b) and methane diffusion (c) along the first $10 \mathrm{~cm}$ of sediment cores for littoral-zone (light blue) and profundal-zone (blue) areas of Lake Remoray. Symbols represent the different sampling points across Lake Remoray (see Fig. 1). Methane diffusion (c) represents the sum of methane fluxes calculated between each stratum for each sampling point. 
(a)

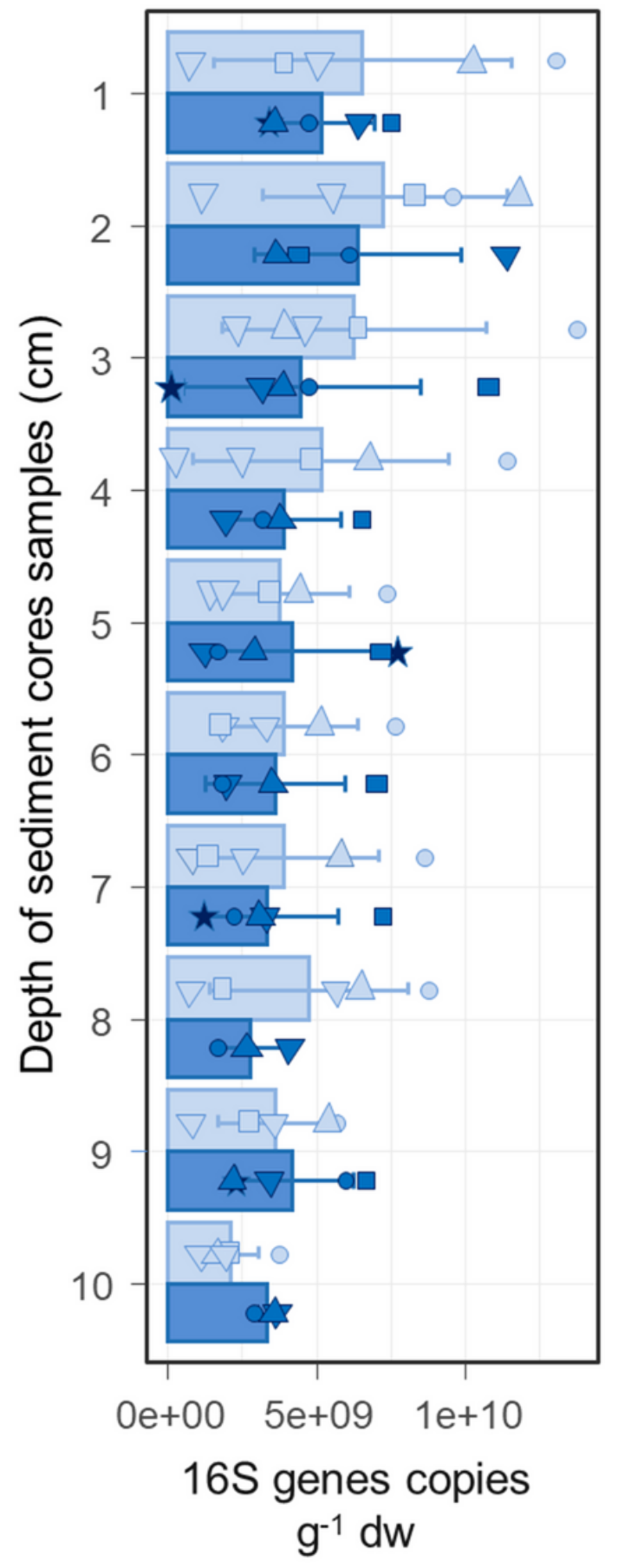

(b)

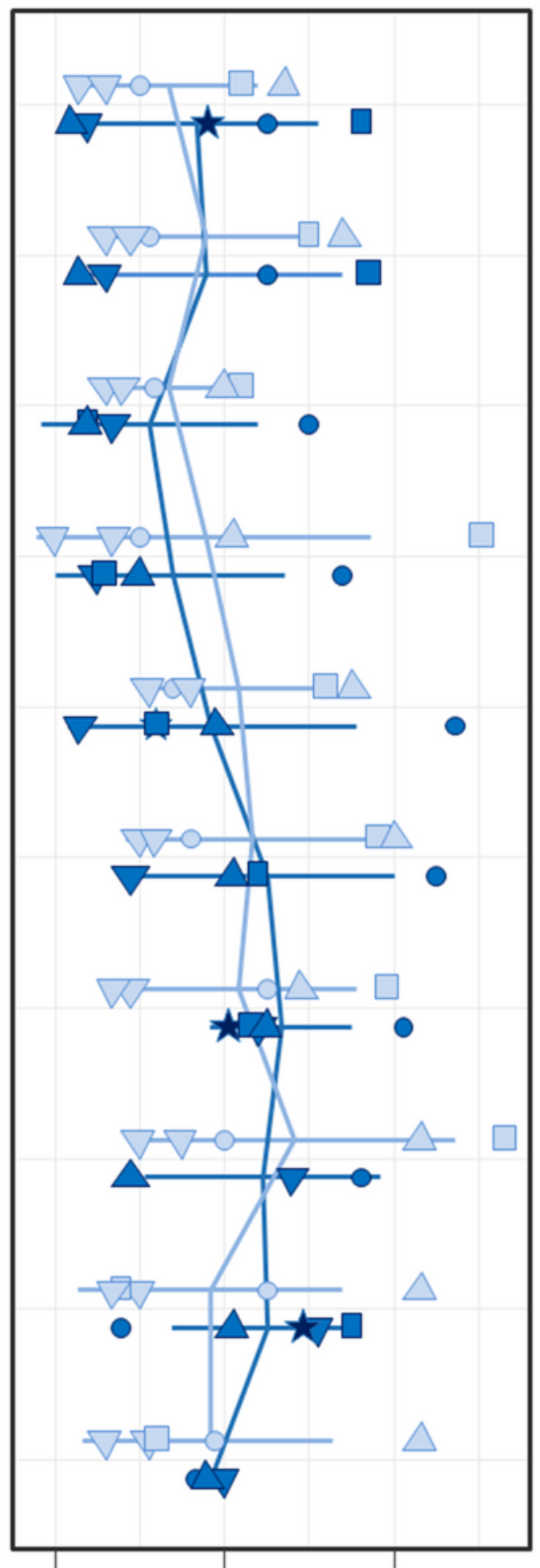

$0.0 \quad 0.2 \quad 0.4$

mcrA/16S ratio (c)

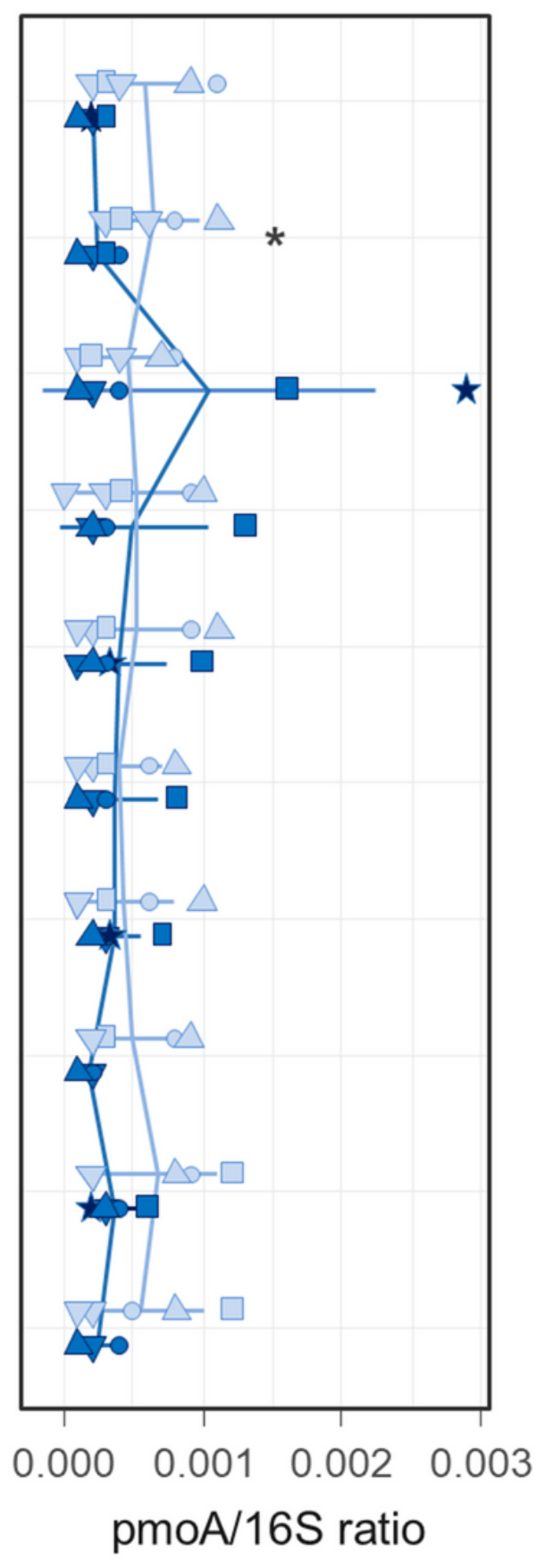

Figure 4

Microbial density (a), genetic potential of methanogens (b) and methanotrophs (b) along the sediment cores for littoral zone (light blue) and profundal-zone (blue) area of Lake Remoray. Histograms and vertical lines represent the averages of sampling points from littoral and profundal zones for each sampling stratum of sediment cores, with standard deviation $(n=5)$. Symbols represent the different sampling points across Lake Remoray (see Fig. 1). Asterisks indicate significant differences between littoral-zone and profundal-zone sediment. 

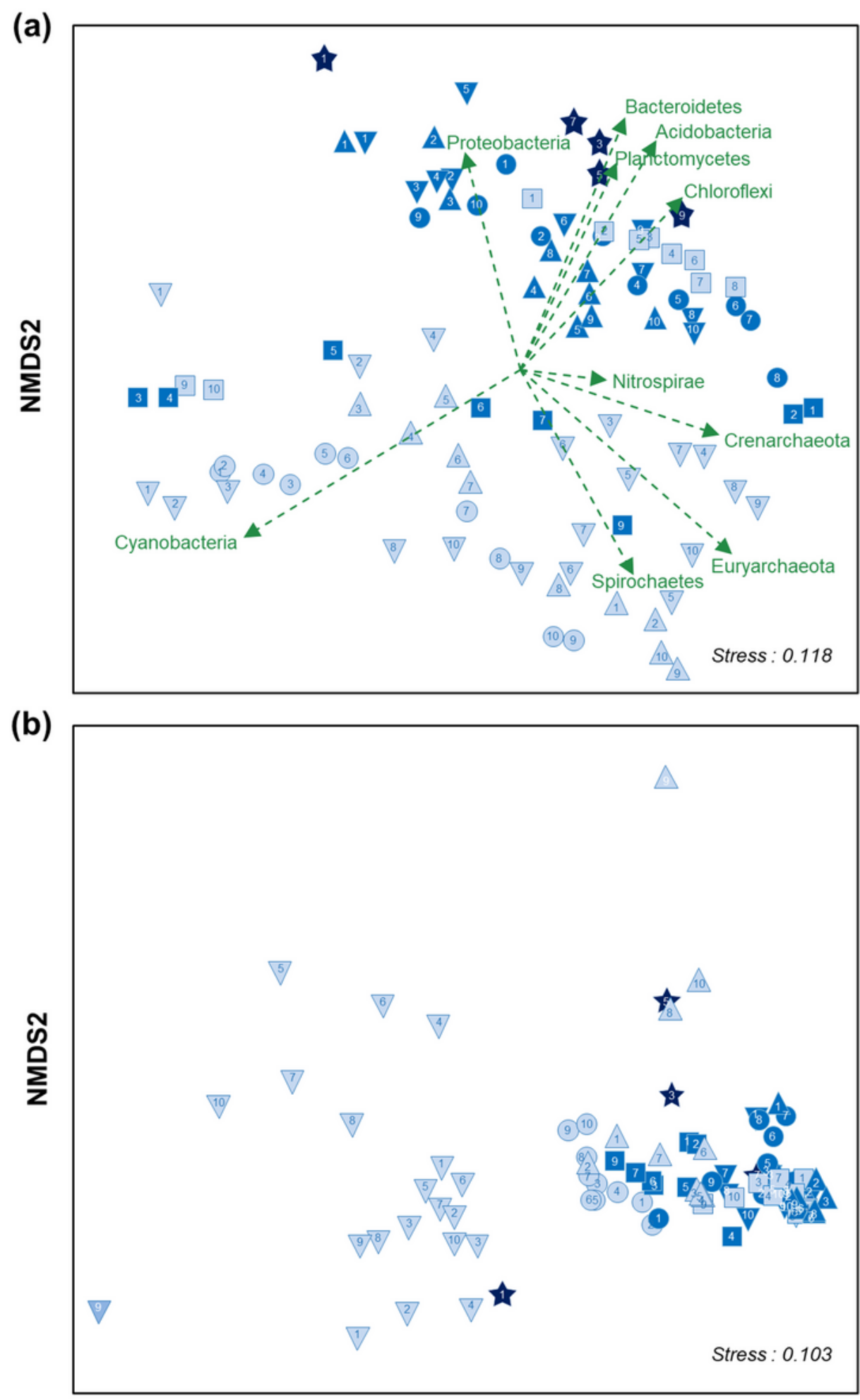

alnmen

\section{Figure 5}

Non-metric multidimensional scaling (NMDS) ordination plot derived from weighted pairwise Unifrac distances for (a) bacterial and archaeal and (b) methanogen communities for all strata of sediment cores sampled across Lake Remoray. Symbols represent sampling points, and numbers inside represent the sediment stratum. Stress values for the two ordination plots were $<0.2$, which indicates that these data were well represented by the two-dimensional scaling. Vectors in the bi-plot overlay represent significant 
correlations $(\mathrm{P}<0.05)$ between phylum abundance and genetic structure. The angle and length of the vector indicate the direction and strength of the variable.

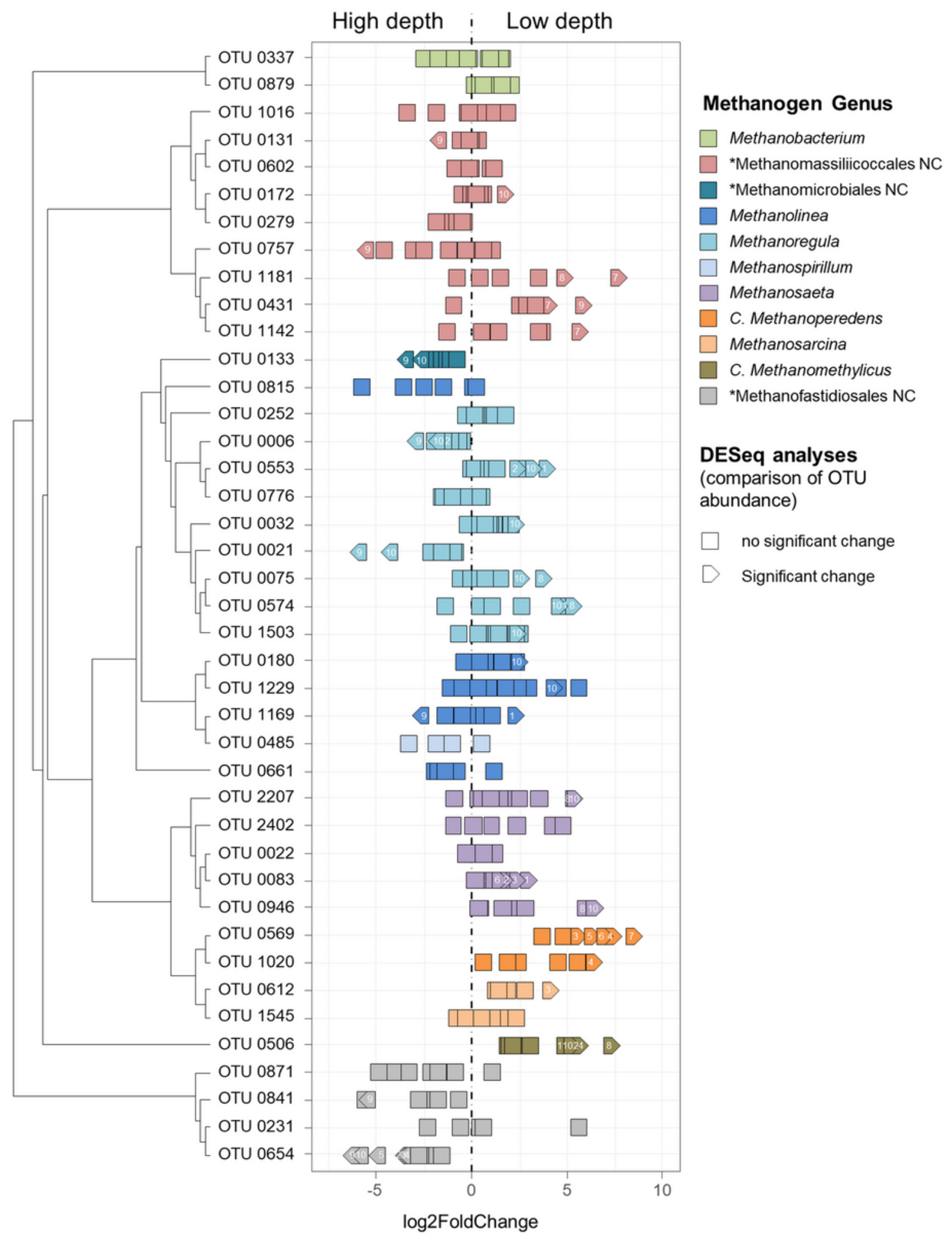

Figure 6

Phylogenetic tree of 41 methanogen OTUs extracted from the 16S rRNA gene sequencing dataset (a) and log2 fold changes in relative abundance of methanogen OTUs between sediment cores sampled in littoral-zone and profundal-zone areas of Lake Remoray (b). Each symbol represents the comparison 
between littoral-zone and profundal-zone areas for a given stratum and OTU. Numbers in white represent the stratum depths (in $\mathrm{cm}$ ) where significant change was observed. OTUs not classified at genus level (NC) were assigned to order level.

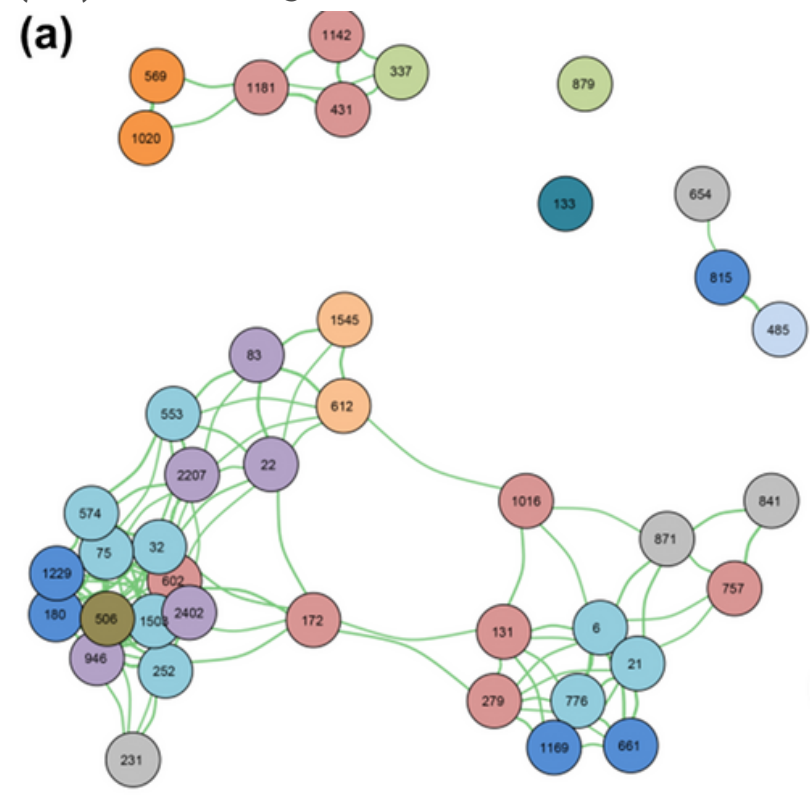

\section{(b)}
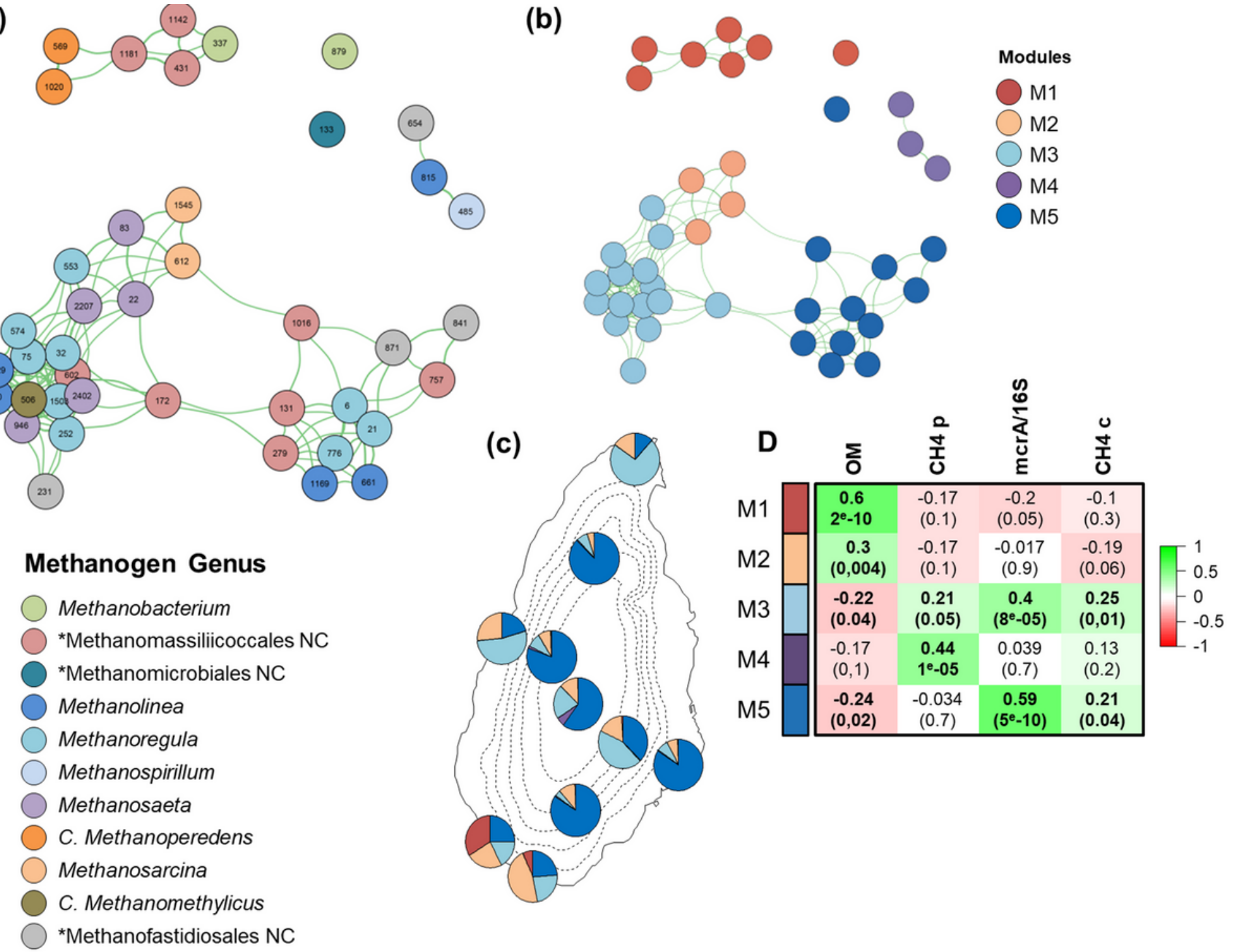

Figure 7

Co-occurrence networks of methanogen communities in the first $10 \mathrm{~cm}$ of Lake Remoray sediment cores. Nodes (circles) represent the methanogen OTU coloured by (a) taxonomic affiliation at genus level and (b) by modules. The edges (lines) represent significant Pearson's correlations at R>0.5. Green and red lines indicate positive and negative relationships between OTUs. The map of Lake Remoray (c) shows the proportion of modules within methanogen communities. The correlation plot (d) represents modulefunctional parameter relationships according to Pearson's correlations between eigengenes of modules and $\mathrm{CH} 4$-cycling parameters (OM, Organic Matter concentration; $\mathrm{CH} 4 \mathrm{p}$, methane production; mcrA/16S rRNA genes ratio, the genetic potential of methanogenesis; $\mathrm{CH} 4 \mathrm{c}$, methane concentration). Numbers in bold indicate significant correlations with $\mathrm{P}$ values in brackets. 